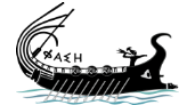

journal.phaselis.org
PHASELIS

Issue IV (2018)
Disiplinlerarası Akdeniz Araştırmaları Dergisi

Journal of Interdisciplinary Mediterranean Studies
The Just Ruler of the Age - Exhibiting Legitimacy for Rule through Visual Representation, as in the Written and Inscribed Record: On the Meanings Conveyed by the Creatures Depicted on 8-Pointed Tiles from Rūm Seljuk $13^{\text {th }}$ c. Palaces, Pavilions and Bath-Houses: The Jinn

Çağın Adaletli Hükümdarı - Yazılı ve Yazıtı Kayıtlarda Görsel Tasarımlar Vasıtasıyla Kuralların Meşruluğunun Sergilenmesi: XIII. Yüzyıl Rum Selçuklularına Ait Saraylar, Köşkler ve Hamamlardaki Sekiz Köşeli Çinilerde Betimlenen Yaratıkların Anlamları Üzerine: Cinler

\section{T. Mikail P. DUGGAN}

The entire contents of this journal, Phaselis: Journal of Interdisciplinary Mediterranean Studies, is open to users and it is an 'open access' journal. Users are able to read the full texts, to download, to copy, print and distribute without obtaining the permission of the editor and author(s). However, all references to the articles published in the e-journal Phaselis are to indicate through reference the source of the citation from this journal.

Phaselis: Journal of Interdisciplinary Mediterranean Studies is a peer-reviewed journal and the articles which have had their peer reviewing process completed will be published on the web-site (journal.phaselis.org) in the year of the journal's issue (e.g. Issue III: JanuaryDecember 2017). At the end of December 2017 the year's issue is completed and Issue IV: January-December 2018 will begin.

Responsibility for the articles published in this journal remains with the authors.

Citation T. M. P. DUGGAN, "The Just Ruler of the Age - Exhibiting Legitimacy for Rule through Visual Representation, as in the Written and Inscribed Record: On the Meanings Conveyed by the Creatures Depicted on 8-Pointed Tiles from Rūm Seljuk $13^{\text {th }} \mathrm{c}$. Palaces, Pavilions and Bath-Houses: The Jinn". Phaselis IV (2018) 389-421.

http://dx.doi.org/10.18367/Pha.18024

Received Date: 24.09.2018 | Acceptance Date: 19.11.2018

Online Publication Date: 30.12.2018

Editing

Phaselis Research Project

www.phaselis.org 


\title{
The Just Ruler of the Age - Exhibiting Legitimacy for Rule through Visual Representation, as in the Written and Inscribed Record: On the Meanings Conveyed by the Creatures Depicted on 8-Pointed Tiles from Rūm Seljuk $13^{\text {th }}$ c. Palaces, Pavilions and Bath-Houses: The Jinn
}

\author{
Çağın Adaletli Hükümdarı - Yazılı ve Yazıtı Kayıtlarda Görsel Tasarımlar Vasıtasıyla \\ Kuralların Meşruluğunun Sergilenmesi: XIII. Yüzyıl Rum Selçuklularına Ait Saraylar, Köşkler \\ ve Hamamlardaki Sekiz Köşeli Çinilerde Betimlenen Yaratıkların Anlamları Üzerine: Cinler
}

\author{
T. Mikail P. Duggan*
}

\begin{abstract}
This article is of three parts. The first part provides a brief account of the past 50 years of publications concerning the figures depicted on the 8-pointed tiles in the tile-work revetments of Seljuk palaces and related structures, in which no meaningful explantion has been offered as to the reason for the use of the four figural types employed in these depictions. The use of these four figural types was to state in the visual language of design that the Seljuk ruler was to be understood as being "The Second Sulaymān," "The Sulaymān of the Age". Part II, in brief, addresses the matter of titulature and of its sources, both Caliphal through investiture, and those derived from the Qur'an, and works such as the various Qișaș al-Anbiyā,' those literary sources that found expression in the titles of rulers and in the representation of these titles in both script and in visual forms (design) at that time. Part III addresses the matter of the so-called "hybrid" or "mythical creatures" depicted on this tilework, that is, the pictorial representations of some of the members of one of the armies under Sulaymān's command - the jinn - the references made to them, the record of their appearance in the available sources and the record of their presence in the related literature, and it concludes with examples of the depiction of them on these $13^{\text {th }}$ c. Seljuk tile-work revetments, depictions that differ markedly from their later representation in Ilkhanid, Timurid and Ottoman art.
\end{abstract}

Keywords: Seljuk Sultan, Titles, Palaces, Second Sulaymān, Jinn, Just Rule

Öz: Bu makale üç kısımdan oluşmaktadır. İlk kısım, Selçuklu sarayları ve ilişkili yapılardaki çini kaplamalarındaki sekiz köşeli çiniler üzerinde tasvir edilen figürlere ilişkin yayınların 50 yıllık bir özetini içermektedir. Zira bu yapılardaki tasvirlerde kullanılan dört figür tipinin kullanım nedeni ile ilgili anlamlı bir açıklama yapılmamıştır. Kullanılan bu dört figür tipinin kullanımı görsel tasarım dilinde, Selçuklu hükümdarının "ikinci Süleyman”, "Çağın Süleymanı” olarak anlaşılması gerektiği belirtilmektedir. İkinci kısım, özetle, adlandırma ve bunun kaynaklarına ilişkin hususu, hem atama hem de Kur'an yoluyla hilafeti, ve de muhtelif Kısas-ı enbiyâ gibi eserleri, hükümdarların unvanlarının ve bu unvanların o dönemde yazılı ve görsel tasarımlardaki açıklamalarının bulunduğu edebi kaynakları ele alır. Üçüncü kısım ise bu çiniler üzerinde tasvir edilen "hibrid" ya da "mitolojik yaratıklar" olarak adlandırılan konuya ilişkindir. Yani Süleyman'nın komutası altındaki ordulardan birinin bazı üyelerinin resimli tasvirine, -cinler- üzerine yapılan referanslara, mevcut kaynaklardaki görünüşlerine, ilişkili literatürdeki varlıklarına ilişkindir. Bu kısım XIII. yüzyıl Selçuklu çini kaplamaları üzerindeki tasvirlerine ve İlhanlı, Timur ve Osmanlı sanatlarında kayda değer derecede farklılık gösteren sonraki betimlemelerine ilişkin örneklerle sonlanmaktadır.

Anahtar sözcükler: Sultan Selçuk, Çiniler, Saraylar, İkinci Süleyman, Cinler, Adaletli Yönetim

* Lecturer, Akdeniz University, Mediterranean Civilisations Research Institute, Antalya. tmpduggan@yahoo.com 
The literature refering to Rūm Seljuk palace figural tilework over the past more than fifty years has offered little in the way of any coherent explanation for the extraordinarily varied range of creatures that are depicted on the eight-pointed tiles of the form of a Seal of Sulaymann device, in these tiled revetments and on the surviving fragments thereof. They have instead often simply been described and divided into groups, animals and birds, so-called otherworldy-mythical creatures, and, people; while the reason for this variety of creatures inhabiting the same wall space in this palace/ruler context has remained almost entirely unaddressed. For example in 1966 Michael Pereira wrote: "The tiles found at the palace of Kubad-Abad on the shores of Lake Beyjehir are of especial interest, for they depict, in addition to the usual geometric designs, the faces and figures of both men and women, as well as such birds and animals as peacocks and eagles, horses and elephants." "In 1976 Gönül Öney related: "As the Kubadabad tiles indicate, perhaps the most interesting figures appearing on Seljuk palace tiles are the various animals related to hunting and the imaginary or magical animals. Various animals that can be categorized as game are shown in widely varying and highly artistic compositions. Sometimes, these figures are stylized; at other times, they are more naturalistic, but in all cases they are shown in graceful motion, running or jumping. Hunting dogs, panthers, foxes, wolves, hares, antelopes, wild mountain goats, wild asses, bears and horses present a colourful menagerie. Also included are various birds and ducks, depicted in remarkably clever and highly artistic compositions. Among the representations on palace tiles from Kubadabad, the 'fabulous' animals have a special place. A magical world of imagination is reflected on the walls by sphinxes, sirens, griffons, double dragons and double-headed eagles. Sphinxes and sirens, being magical creatures believed to protect the Sultan, are repeated with frequency." ${ }^{2}$ While in the 1980 fasicule of the Encyclopedia of Islam they were described by Michael Meinecke as showing, "a variety of iconographic themes side-by-side" not exhibiting a coherent iconography, which itself seems to be a rather odd idea. He wrote: "The tiles, datable ca. 627/1230 or a little later, show a variety of iconographic themes side-by-side, apparently reflecting the multiple functions of the building, as a Royal residence and as a hunting lodge; on the one hand, there are symbols of power like the soveriegn enthroned, eagles bearing the inscription al-sultann on their breasts or a lion; and on the other, astrological symbols and fabulous creatures, or trees of life which may well be allusions to paradise. Finally there are the stylised animal figures, with falcons or horses together with game animals like foxes, hares, deer, bears, etc." ${ }^{3}$ If this were in fact the case, that the decoration on a palace revetment carried a variety iconographic themes linked to a variety of palace functions, it would be a type of palace decoration perhaps unique to the structures of the Rūm Seljuk ruler. In 1986 Gönül Öney wrote: "The figural tiles are decorated with figures of the sultan, harem women, courtiers and servants. However, the most interesting figures are the various animals related to hunting and the imaginary or magical animals. Such creatures as the sphinx, siren, single and double-headed eagles, single and paired peacocks, paired birds flanking the tree of life and dragon create a magical world of the imagination. They are all symbolic representations of the rich figural world of the Seljuks. Animals related to hunting, such as the fox, hare, wolf, mountain goat, wild ass, bear, lion, falcon, hawk and antelope are in widely varying and highly artistic compositions." ${ }^{4}$ In 1989, in Marianne Mehling's volume on Turkey, Pitty Schöttler wrote: "The Kubadabad palace tiles are painted with all sorts of animals which can be hunted and also fabulous creatures, usually as elements of skilful compositions, and showing graceful movement. Sphinxes, dragons, double eagles, sirens and gryphons were intended to protect the palace." In 2005, Nazan Ölçer wrote: "Among the tiles from the Seljuk palaces, a distinctive group of figural tiles from Qubadabad throws light on the spiritual world of the Anatolian Seljuks. Magical legendary creatures such as harpies and sphinxes are portrayed in the same pose and garb as the sultan, together with double-headed eagles, symbols of power and light." ${ }^{6}$, and, in

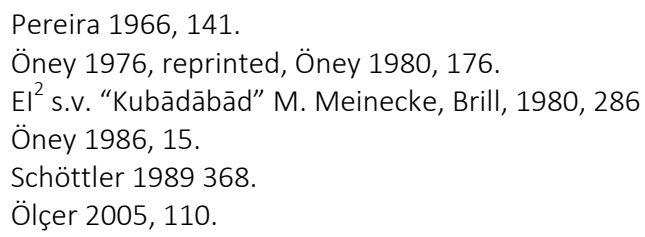


the same 2005 volume, Oya Pançaroğlu wrote: "Seen from this angle, Qubadabad's tiles may also be considered to function as a mirror reflecting the continuum of temporal creation centred on the sultan - in person or in proxy through inscribed double-headed eagles-and spreading out to his subjects, to the multiplicity of animals, and to the imaginary margins of the world." In 2008 Rüçhan Arık wrote, "The tiles in the Great and Small Palaces of Kubad Abad fuse the iconography reflecting (the) Seljuk's symbolic universe with an interesting pictorial style and create a fairy tale atmosphere. The most significant figure of this fairy-tale world and the symbol of the palace and the sultan, the double-headed eagle appears with all its majesty. Other birds appear almost as if they are flying around it. The influence of nomadic art, known as "the animal style" that developed in Central Asia from the $7^{\text {th }}$ century BC onwards, which was shared by all Central Asian peoples, including the Turks, has played a role in the origins of these tiles, in terms of their themes and iconography." ${ }^{8}$ In 2015 Scott Redford wrote, "While it is easy to hypothesise that the images of courtiers, hunting animals and waterfowl relate to the activities of the court, they do not resolve into a series or a story and seem randomly to be intersected with figures that are astrological or mythical, evoking a mythical realm in which scenes and activities of the court are linked to fabulous creatures and mythical beasts, perhaps, but without narrative or iconographic programme... Or did the single figures on these tile dadoes also "stand in" for the activities of the court, populating spaces during the long months the palaces lay empty with sphinxes and harpies to guard them?"' Likewise in 2017, Eva R. Hoffman and Scott Redford wrote: "The tiles from the Rum Seljuq palace of Kubadabad, built west of Konya in the mid-1220's (sic.), bear figural imagery that depicts animals both hunter and hunted. They are combined with other tiles depicting astrological and mythic creatures (Redford 2000: 69-76)."10

It was not suggested in these accounts that there are a series of rather well known texts that accurately describe the four types of creatures that are depicted on these tiles, forming a group that would certainly have been easily identified and recognised in the $13^{\text {th }}$ c., as earlier, as being related to a certain famous ruler-figure. This is largely due to the use of a $19^{\text {th }}$ c., classically trained, orientalist originated incorrect terminology in the identification of the members of one of the four groups of these figural depictions on these 8 pointed tiles.

In the $11^{\text {th }}$ c. Abū Ishāq Ahmad ibn Muhammad ibn Ibrāhīm al-Tha'labī al-Naysābūrī, (d. 427-1035) had related in his Arā'is al-Majālis fi qisas al-anbiyā that, "Solomon had an army of 100 parsangs in extent; one quarter men, one quarter Jinn, one quarter beasts, and one quarter birds." ${ }^{11}$, as earlier Abū Ja'far Muhammad ibn Jarīr al-Ṭabarī in his Ta'rīkh al-Rusūl wa al-Mulūk, of c. 916 A.D. had related: "We have heard that Solomon's army [stretched) one hundred parasangs: twenty-five of them consisted of humans, twenty-five of jinn, twenty-five of wild animals, and twenty-five of birds."12, As also, "Then

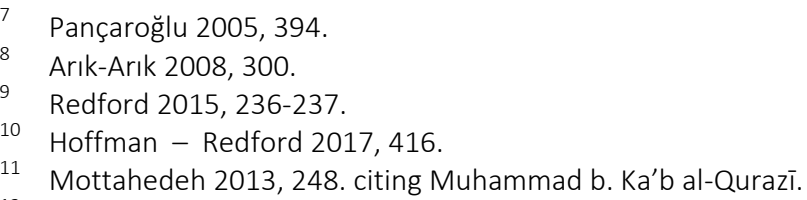

12 Ṭabarī, 1985, III, 154, from M. b. Ibn Ka'b al-Qurazī (d. 736). Ṭabarī also relates: "Solomon asked his own troops, jinn, birds, and whoever of his troops had been present," idem. 162. Likewise, except for the army of animals, as in Qur'ān, Al-Naml 27:17, "And gathered for Solomon were his soldiers of the jinn and men and birds," where the army of soldiers of the animals are unmentioned. Sulaymān's hoopoe had related, "God sent a man named Solomon as a messenger, and humbled before him the wind, the jinn, humans, and birds", also omitting the animals, Tabarī, 1985, III, 158; as likewise, "He put it on his hand, went out, and sat on Sulaymān's throne, and the birds, jinns, and men surrounded him." idem. 169. In the Thousand Nights and One Night in the Extraordinary Tale of the City of Brass, Sulaimān ibn Dāūd is mentioned with his "boundless power over the beasts of the desert, the Afārit of the Air, and Jinn of the sea and under earth." 339 ${ }^{\text {th }}$ Night, Mardrus-Mathers 1996, II, 285; and that, Sulaimān at once assembled, "all his forces, of Jinn, of men, of birds and of animals." $341^{\text {st }}$ Night, MardrusMathers 1996, II, 293. Nasir al-Dīn Al-Rabghūzī somewhat later in his 1311 Qișaș al-Anbiyā' wrote concerning Sulaymān's armies-forces, "His workers were men, demons and fairies (meaning jinn), and all creatures that fly or run; the wind and clouds and animals, poisonous or sharp-toothed." Boeschoten-O'Kane 2015, 334; and he wrote Sulaymān's army in the battle with the army of king 'Ukuz, contained demons and fairies (meaning jinn), human 
Solomon sat in audience upon his throne...And he (Solomon) commanded the demons (jinn) to draw up in ranks, parasangs long; and he gave orders to the human beings, and they drew up in ranks, parasangs long; and he commanded the animals, beasts of prey, birds, and venomous creeping things, and they drew up in ranks, parasangs long; on his right and on his left...The story goes that they (Queen Bilqis and her entourage) passed by squadron after squadron of demons (meaning jinn), human beings, birds, beasts of prey, and animals, and came to a halt before Solomon."13 In the Extraordinary Tale of the City of Brass, which may in part originate in the $9^{\text {th }}$ c., a description of these four armies, the forces under Sulaymān's leadership is given: "When Sulaimān learned the treatment which his envoy had undergone, he grew mightily indignant and at once assembled all his forces of jinn, of men, of birds and of animals. To Asaf ibn Barakhyā he gave command of his human soldiers; to Dimiryāt, king of the Afärit, the leadership of all the forces of the Jinn to the number of sixty millions and also of the troops of animals and birds of prey which he had assembled from earth and sky and sea. Heading the combined force himself, Sulaimān entered the lands of my master and drew his army up in battle array. He set the animals on the two wings in ranks of four abreast, and posted the great birds of prey in the air above them to act as sentinels and spies upon our movements and to hurl themselves upon our men when an opportunity served for tearing out their eyes. He put his human soldiers in the vanguard and the army of the Jinn in the rear; he placed the wazir Asaf ibn Barakhyā on his right and Dimiryāt, king of the Afārit of the air, upon his left. He himself stayed in the centre, sitting upon a throne of porphyry and gold, held up by four elephants, and gave the signal for attack. ${ }^{\prime 14}$ While three of these four groups are explicitly mentioned by name in the Qur'ān sürah an-Naml 27.17, "And his hosts of the djinn and the men and the birds were gathered to him, and they were formed into groups."

Muhyid-din Muhammad b. 'Ali Ibn 'Arabi (1165-1240) in his Fusus al-Hikam, in the Chapter entitled, The Wisdom of Compassion (al-hikmat ar-rahmaniyyah) in the Word of Solomon, provides a description of the dominance obtained and exercised by Sulaymān over the jinn, men, animals, and birds: "And as Solomon pleaded with God for the tasarruf over the jinn and Man and over the animals and birds and all together in the high and low universes, and God bestowed this on him, no nabiyy after him is manifested with that kind of tasarruf." "15 As likewise: "God subjugated to him (Solomon) the high and the low universes. The proof of the low universes being subjected to him is his dominance over the jinn and Man and wild animals and birds, and other sea or land animals. His dominance even passed beyond the animals and prevailed over the elements; thus he subjugated the wind, and the wind blew according to his order. And he subjugated water to himself, so that the fiery satans could dive into it for him."16

In the last decade of the $12^{\text {th }} \mathrm{c}$. Ebû Bekr Necmüddîn Muhammed b. Alî b. Süleymân er-Râvendî in his Rahat-üs-Sudur ve Ayet-üs-Sürur had, it seems to this this author at least, to have clearly indicated the context within which these varied figural depictions on these revetments of Rūm Seljuk Palace tiles were to be understood. He wrote, in reference to the branch of the Great Seljuk family descending from Isra'il son of Seljuk, "The Almighty sent a Solomon from the race of israel such that, the reign he inherited is an exactitude of the period of (Khosru) Nuşirvan and, men, şeytan-devils (meaning unbelieving Jinn), peri (meaning believing Jinn), animals and birds like Solomon." ${ }^{\prime 17}$, of the combination of the representatives of

soldiers, one hundred thousand lions, leopards, tigers, wolves, jackals, flying birds of all sorts, idem., 348. From the surviving figures in moulded plaster from the $12^{\text {th }} \mathrm{c}$. KIlic Arslan II pavilion, Konya, although examples of the birds and animals from amongst the few surviving examples of minā' humans are represented, it seems probable the minā $T$ painted 6-pointed sun-star tile-work presented this same subject, represented by either three (birds, jinns, and men) or four (birds, jinns, animals and men) types of figures.

13 Brinner 2002, 529-530.

$14341^{\text {st }}$ Night, Mardrus-Mathers 1996, II, 293.

15 Arabi 1991, 772.

16 Arabi 1991, 761.

17 Ravendi I, 1999, 85, "Yüce Tanrı İsra'il neslinden bir Süleyman gönderdi ki, ona miras kalmış olan hükümdarlık tıpkı Nuşirvan devrine benzer ve insanlar, şeytan (Jinn), peri (Jinn), hayvan ve kuşlar Süleyman gibi." 
the four armies, men, birds, beasts and jinn, with a ruler described as like Sulaymān, "the second Sulaymān," thereby indicating the Rūm Seljuk ruler was the Just Ruler, as both Sulaymān, İskandar, and Khosru Nuşirvan were understood to have been.

This visual language of symbols concerns the representation of the Just Ruler - more particularly, the model of the Just Ruler provided by the example of the Prophet Sulaymān and was an iconography current in the $12^{\text {th }}$ and $13^{\text {th }}$ centuries, as earlier, with Sulaymān perhaps the best known example of the Just Ruler figure and recorded as such in the Qur'ān, amongst other examples of the Just Ruler in the world $^{18}$. These other examples included: Iskandar-Alexander, Khusrev Nushivan and Jamshid.

Hasan ibn Ali of Tus, Nizam al-Mulk, or rather, Muhammad Mu'izzī Nīshābūrī (d. 218-22 1124-8) ${ }^{19}$ stated in the opening of his Siyar al-Muluk (c. 1092), that the Almighty, "imparts to him (the ruler) such dignity and majesty in the eyes and hearts of men, that under his just rule they may live their lives in constant security and ever wish for his reign to continue." ${ }^{20}$, and there was perhaps no better way of indicating and reminding of the Just Ruler, than through employing the visual language of symbolism concerning Sulaymān, a visual language it is evident was employed on these palace tile-work revetments to indicate that the Rūm Seljuk sultan was to be understood as being the Sulaymān of the Time, the Second Sulaymān, the Just Ruler, in this temporal world.

This article in consequence builds upon the suggestion concerning the depictions on the 8 pointed tiles in the tile-work revetments of the Kubadabad Palace and on the walls of other $13^{\text {th }} \mathrm{c}$. Seljuk Palaces and köşkü-pavillions made in an article on this tile-work of 2006, that: "There is perhaps only one text that can be understood to include all of the motifs that appear on these tiles, that relates to a ruler and to a palace setting, to an army of birds, as on these tiles; to an army of men, as in the depiction of seated and walking courtiers in tiraz; and to an army of jinn, if the winged birds with human faces, the winged lions with human faces and the depiction of dragons-serpents can be understood as representing the jinn; to a ruler "endowed with all good things" 21 and "rightly guided"22; that is, to the references made in the Koran to the Prophet Sulayman."; ${ }^{23}$ an association drawn by the near contemporary Ebû Bekr Necmüddîn Muhammed (d. after 1207) as is noted above. It was suggested in 2006 that the designs on these eight pointed sun-star tiles on the tiled revetments of Seljuk palace and pavillion, as at Kubadabad, as at the Bilqīs-Belkız Palace at Aspendos, etc., present us with representations of the four armies of the Prophet Sulayman: depictions of jinn, men, birds and animals, which were employed in the context of Rūm Seljuk rulers who were described as the "Second Sulaymān," the "Sulaymān of the Age," by their contemporaries. This article suggests that these depictions were employed on these tiled revetments, not only as a visual representation and a reminder that the Seljuk ruler was the "Second Sulaymān," 24 with these representations of the varied members of the four armies under the ruler's command visually reflecting this title; but also, that these designs themselves both represented, and were at that time understood to present an expression of legitimacy for rule, to indicate, The Just Ruler, as is recorded in contemporary inscriptions and texts; as in the extensive Advice to Princes-Counsel to Princes, nasīhat al-mulūk type literature of the period ${ }^{25}$, through the references to Seljuk Sultans' as the "Second Sulaymān" (as also, likewise in reference to the Just Ruler, "The Second Alexander" - "The Alexander of the Age," as likewise through reference in inscriptions to Jamshid and the Just Khusrev, as also in the citations from Firdawsi's Shahname in inscriptions on palace and city walls ${ }^{26}$, etc.), thereby presenting reminders to the $13^{\text {th }} \mathrm{c}$.

On this see for example Lafrate 2015.

For the matter of authorship, see: Khismatulin 2015.

20 Darke 1978, 9.

21 Qur'an Sura 27 Al-Naml: 16.

22 Qur'an Sura 6: Al-An'am: 84.

23 Duggan 2006, 2006-7, 206-207.

24 See on this also Lafrate 2015.

25 On this literature, seen in the wider context and the difference in treatment, Orient and Occident, Darling 2013.

26 Bibi 1996, I, 273. 
viewer through depictions in both written texts and inscriptions, and, through the visual imagery employed, that they were in the realm of the Second Sulaymān, that is, the Just Ruler of the Time/Age.

Part II

Both the visual language of the symbolism employed on these 8 pointed tiles ${ }^{27}$, indicating The Second Sulaymān, and the titles publicly exhibited through inscriptions seem to have presented a part of the Rūm Seljuk rulers' claim to legitimacy for rule. This seems also to have been the case with the use of the zigzag design, which remains today in situ on Seljuk city walls, as at Alanya, as on Kırkgöz han, as on Alara han and as formerly on many other Seljuk state buildings ${ }^{28}$, a design which also appears on some of the cross-tiles of the "lattice" of these palace tile-work revetments, reflecting and re-iterating the Rūm Seljuk Sultan's lakab, qasim amir al-mu'minin, "Partner-Associate of the Caliph" from 1228-1229 onwards ${ }^{29}$. However, the source of the title, The Second Sulaymān and the related group, was not the Abbasid Caliph, unlike titles such as: sultan al-mu'azzam, sultan al-azam and qasim amir al-mu'minin.

Legitimacy for rule as a Muslim Turkish ruler under the Abbasid Caliphs in the pre-Mongol period, Ghaznavid, Seljuk, Atabek, Khwarizm Shah etc., depended upon the Sultan's investiture as Sultan by the Caliph or by his envoy-representative, a charter (manshair) granting him territory, a standard, seal, sword, a splendid robe of honour etc., and the awarding, display and use of titles. Not the least of these titles being that which remarkably described a ruler as qasim amir al-mu'minin, that is, the Associate or the Partner of the Caliph. The title amir al-mu'minin was first used by the second Caliph 'Umar b. al-Khattab ${ }^{30}$. The awarding of titles to rulers by the Abbasid Caliph in Bagdad from the mid $\mathrm{XI}^{\text {th }}$ century onwards in exchange for gifts was an important diplomatic and financial resource in strengthening the weakened Caliphate; given the competitive desire on the part of rulers to obtain wider recognition through obtaining higher titles from the Caliph, than those awarded to neighbouring rulers. This was recorded by Muhammad Mu'izzī Nīshābūrī (d. 218-22 1124-8), under the name of Hasan ibn Ali of Tus, Nizam Al-Mulk ${ }^{31}$, and who described the Ghaznavid, Abul-Qāsim Maḥmūd ibn Sebüktegīn, Mahmud of Ghazna's (998-1030) desire for more titles to add to the titles the Abbasid Caliph alQadir (991-1031) bestowed upon him of Yamin-ud-Dawla (The Right Arm of the Caliphate) and Amin al-Milla, "The Trusted One of the Religious Community"32 in 999 and, he finally obtained in addition, the titles Nizam ud Din (1013) and Kahf ud Dawlah wa'l Islam (November- December 1026); although Nizam Al-Mulk's account ${ }^{33}$ stressed that the Caliph Abu'l'Abbās al-Qādir bi'llah (991-1031) was unwilling to grant futher titles to him in the period after 999, regarding them as

27 It can be proposed that the 8-pointed sun-star shape was associated with the Prophet Sulaymān and with the Qubbat al-Sakhrah from the end of the VII ${ }^{\text {th }} \mathrm{c}$. onwards, and, at times with the form of the Seal of Sulaymān, "The 8-pointed star shape, known as Khatem Sulemani, meaning the Solomon's seal. This shape, ..., is the most ubiquitous shape that occurs in Islamic patterns. If we were forced to pick one shape that characterizes Islamic patterns, then it would have to be this one" Jan-Shaker 2007, 14.

28 Duggan 2008, 324, 330, 332, 335, 336, 341-343.

29 Duggan 2017 forthcoming. For examples, Arık-Arık 2008, 239, 243, 252, 253, 283, 312, 313, 350c; Arık 2000, Figs. $53,109,216,222,225,227-228$.

30 Anas 2013, 37, 76, 129, 167, 168, 280, 349, 417.

31 For the matter of authorship, see: Khismatulin 2015, who reasonably attributes it to Muhammad Mu'izzi Nìshābūrī (d. 218-222/1124-8).

32 Gardizi records the insignia of his investiture (fahd) from Caliph al-Qadir Bi'llah (d. 1031) and gives a short account of the ceremony by which Mahmud was given the titles of "Right Arm of the Caliphate" (yamin addawlat) and "Trustee of the Community" (amin al-milla), along with such symbols of his official dignity as the banner. In Nizam al-Mulk's account these two titles were not awarded to the sultan at the same time.

33 Khismatulin 2015, Op cit. fn. 14. 
things given to an ignorant ruler, to "swell his reputation and make up for his lack of wisdom" 34 not, the Caliph indicated, to rulers of the stature of Sultan Mahmud of Ghazna. To the Caliph, as to Chinese Gordon and Richard Burton in the $19^{\text {th }} \mathrm{c}$., what was done was a matter, as Burton relates of "Hasab" (= quantity), the honour a man acquires for himself; as opposed to "Nasab" (genealogy) honours inherited from ancestry: the Arabic well expresses my old motto (adopted by Chinese Charles George Gordon) (of), "Honour, not Honours" ${ }^{\prime 35}$. In the chapter entitled, On the Subject of Titles ${ }^{36}$ in The Book of Government, or, Rules for Kings: The Siyar Al-Muluk, Or, Siyasat-nama, Muhammad Mu'izzī Nīshābūrī under the name of Hasan ibn Ali of Tus, Nizam AlMulk ${ }^{37}$ writes: "Likewise the amirs of the Turks have always been given the titles Husam adDaula [Sword of the Caliphate], Saif ad-Daula [Sabre of the Caliphate], Yamin ad-Daula [Right Hand of the Caliphate], Shams ad-Daula [Sun of the Caliphate], and suchlike"138.

The laqab, qasim amir al-mu'minin, the highest title awarded by the Abbasid Caliph to an Islamic ruler was a title that seems to have been awarded almost exclusively to Turkish rulers by Abbasid Caliphs ${ }^{39}$, but which was first given to the Buwayhid, Khusraw Fīrūz, al-Malik al-Rahim b. Abu Kalijar (1048-1055), who used the term, "Associate of the Caliph" as his official title-rank (qasīm amìr al-mu'minin) ${ }^{40}$. The Shafi Abu 'I-Hassan 'Ali al-Mawārdī (974-1058), author of the Kitab al-Ahkam al-Sultaniyya-The Book of Ordinances of Government, had suggest that the Caliph had to be a member of the Quraysh and this title was perhaps the closest possible for a non-Quraysh, and it may be that in his negotiations for Caliphal recognition from the Buwayhids, he had suggested or offered it on behalf of Abu Ja'far al-Qā'im (1031-75) to Khusraw Firūz. This title was then given by Abbasid Caliphs to Great Seljuk Sultans including: Tuğrul in $1058^{41}$ following the Buwayhid precedent and then to Malik Shah ${ }^{42}$, and the somewhat younger and influential Abd al-Malik al-Juwayni (1028-1085) stated the Calph did not necessarily have to be a member of the Quraysh, building upon Abu Ja'far al-Qā'im's SunniSeljuk alliance, and going much further in suggesting the unification of the roles of Caliph and Sultan in a single figure, supporting the Great Seljuk Sultan's Malik Shah's aspirations to the Caliphate, no doubt stimulated by Sultan Tuğrul's marriage alliance with the Caliph. It was a title which was then given to the Great Seljuk Sultan Muhammad Tapar (1105-18) ${ }^{43}$ in the reign of the Caliph al-Mustazhir, to Süleyman b. Muhammad b. Malikshah $(511 / 1118)^{44}$, to Mas'ud b. Muhammad (1134-1152), ${ }^{45}$ to Arslan (Shah) b. Tuğrul II (1161-1176) ${ }^{46}$ and to Abū Talib Tuğrul III

34 Darke 1978, 150.

35 Burton 2008, Vol. IV, 171

36 Darke 1978, 148-157.

37 Khismatulin 2015.

38 Darke 1978, 148, ad-Daula can more properly at this time be translated-understood as the Caliphate, rather than as the Empire and has been here altered

39 Northrup 1998, 174, states "Although this title had been used by the Buyids, neither the Saljuqs nor the Ayyubids had favoured it" which seems somewhat incorrect, see for example Eddé, "L'un des plus honorifiques était qasim amir al-mu'minin (bras droit de l'émir des croyants) qui fut porte par les grands sultans seldjouquides et par ceux d'Anatolie" Eddé 1999, 202.

40 Blair 1992, 119.

41 Blair 1992, 119, gives 1060; Frenkel 2014, 18.

42 Ravendi I, 1999, 83.

43 Bosworth 2010, 56; Ravendi I, 1999, 83.

44 Ravendi 1999, II, 262.

45 Bosworth 2010, 72; Ravendi I, 1999, 84.

46 Bosworth 2010, 113; Ravendi I, 1999, 84. 
b. Arslan (Shah) 1176-94 ${ }^{47}$. It was probably also given to the Ghaznavid Masud III b. Ibrahim (1099-1115). It was a title employed by the Ghūrid, Muhammad b. Sam (1162-1206) ${ }^{48}$ and the title qasim amir al-mu'minin was later given to and used by the Delhi Sultan Iltutmish ${ }^{49}$ (121136) and by Ghiyath al-Dīn 'Iwad of Bengal (1213-1227) $)^{50}$. From A.H. 626-1228/9 A.D. the Rūm Seljuk Sultan Alaeddin Keykubat I. obtained this highest laqab-title from the Abbasid Caliph, Abū Ja'far al-Mustansir (1226-1242), of qasim amir al-mu'minin-Associate/Partner of the Caliph and was thereby associated as Just Ruler with both the Caliph and the haramayn. This title was employed in his inscriptions at Divriği, on his Sultanhan, at 'Alā'ıyya-Alanya, Tokat and Sancir ${ }^{51}$. This laqab was also employed by Sultan Ghiyath al-Dīn Keyhusrev II and by Sultan Rukn al-Dīn Qilij Arslan IV (r.1248-1264) in his first reign ${ }^{52}$. It was a title later given by Abu'l Qāsim alMustansir, the new Abbasid Caliph in Cairo, to the Mamlūke Sultan Baybars from 1261, and in a slightly different form, qasım fı qiyyām bi-I-haqq, Associate in Supporting the True Religion, which was given to Baybars in November $1262^{53}$ by the new Caliph al-Hākim b. amr Allāh (12611302). The lakab, qasimm amìr al-mu'minin was given and employed by other Mamlūke Sultans: Qalāwūn, Baraka Qān, Salāmish, Qalā'ūn, al-Ashraf Khalīl, Al-Adil Kitbughā and by Baybars II. It has been suggested elsewhere that it was the awarding of this title of Associate or Partner with the Abbasid Caliph and so with the haramayn that resulted in the widespread use in territory under the rule of Turkish Sultans of the zigzag design employed as a marker of legitimacy through the association of this design with the Abbasid Caliphs and their guardianship over the haramayn ${ }^{54}$.

Two titles that were not given by the caliph but which are recorded in literary texts and from the epigraphic evidence seem to be characteristic of Turkish rulers, the title, "The Second Sulaymān-Süleyman-Solomon" - "The Sulaymān of the Age" recorded in texts and through design; and, "The Second Dhū'l-Qarnayn/Zū'l-Qarnain/Iskandar" - "The Dhū'l-Qarnayn of the Age" - "The Alexander of the Age," recorded in literary texts and in the epigraphic evidence. Both Sulaymān and Alexander-Dhū "I-Qarnayn were understood to have been both true believers and world conquerors.

\section{"The Second Sulaymān-Süleyman-Solomon" - "The Sulaymān of the Age"}

The title of "The Second Sulaymān" was given to the first Turkish ruler to use the title Sultan, meaning power-authority, Yamīn-ud-Dawla Abul-Qāșim Maḥmūd ibn Sebüktegīn, Mahmud of

47 Ravendi I, 1999, 84

48 "Al-malik wa'l-sultan al-mu'azzam shahanshah al-a'zam malik riqab al-umam sultan al-salatin fi'l-'alam ghiyath al-dunya wa'l-dln mu'izz al-Islam wa'l-muslim/n qahir al-kafara wa'l-mulhidin qami' al-bid'a wa'l-mutamarridin 'adud al-dawla al-qahira taj al-milla al-zahira jalal al-umma al-bahira nizam al-'alam abu al-fath Muhammad ibn Sam, qasim amir al-mu'minin".

$49 \mathrm{EI}^{2}$ 1982, s.v. "Lakab" 629.

50 Ghiyath al-dunya wa'l-din Abu'l-Fath 'Iwad bin al-Husayn qasim amir al-mu'minin Sultan al-Salatin Mu'izz aldunya wa'l-din Abu'l Muzaffar 'ala yad Nasir Amir al-Mu'minin. Obv.: Al-Nasir al-din Allah Amir al-Mu'minin. Obverse margin date in words: hijri 616.

51 See Lloyd-Rice 1958, 53.

52 Struck on a Dinar minted in Sivas 642 AH, 1244-5 see Yapi, as on a 646/1248-1249 dirham minted in Sivas, "alsultan al-a'zam rukn al-dunya wa'l-din qilij arslan ibn kaykhusraw, qasim amir al-mu'minin - the Supreme Sultan, Pillar of the World and the Faith, Qilij Arslan ibn Kaykhuraw, Partner of the Commander of the Faithful" http://davidmus.dk/en/collections/islamic/dynasties/seljuks-of-rum/coins/c103?back=1\&show=comment.

53 D. Aigle, Legitimizing A Low-Born, Regicide Monarch: The Case Of The Mamluk Sultan Baybars And The Ilkhans In The Thirteenth Century, 1-18, 2009, 4, at: https://hal.inria.fr/docs/00/38/33/36/PDF/Baybars.pdf

54 For further on this matter see Duggan 2019 forthcoming. 
Ghazna 998-1031, by Badi uz Zaman al-Hamadhani (d. 1009) ${ }^{55}$. And it was given to subsequent Ghaznavid Sultans: Ma'sud III $1099-1115$ and to Sultan Malik Arslan Ma'sud b. Ma'sud III (r. 1116) Mas'ud-i Sa'd-i Salman ${ }^{57}$; as also to the Great Seljuk Sultan Sanjar 1118-1157, by Khaqani ${ }^{58}$ (1106/7-1185), and to the Salghurid ruler of Fars, Sad I b. Zangi (1198-1226), entitled "heir to the kingdom of Solomon" and to his son, Muzaffarud-Dīn, Qutlugh Khān Abu Bakr Muhammad b. Sad I b. Zangi (1226-1260) "Lord Commander of the Kingdom of Solomon, the Just Shahinshah" and "heir to the kingdom of Solomon"59.

Ebû Bekr Necmüddîn Muhammed b. Alî b. Süleymân er-Râvendî in his Rahat-üs-Sudur ve Ayet-üs-Sürur, completed by 1206, repeatedly draws the parallel between the Prophet Süleyman and Seljuk rulers ${ }^{60}$ and refers to the Seljuk rulers as being like Süleyman, with the same four armies, of people, of jinn, both believing and unbelieving, beasts and birds ${ }^{61}$. Ibn Bibi describes the arrival of the Seljuks in the lands of Rūm ${ }^{62}$ as being brought into this territory by the wind-breath of the Prophet Sulaymān ${ }^{63}$, a reference to both the Prophet Sulaymān (AlAnbiya 21:81; Sad 38:36) and linked to the name and actions of the founder of the Rüm Seljuk Sultanate, Melik Sulaymān b. Qutlumush (1081-6) $)^{64}$. The name Sulaymān was also given to one of the sons of Sultan Kılıç Arslan II (r. 1156-92), Sultan Sulaymān-Shāh Rukn al-Dīn (r. 11971204), while ibn Bibi also described Sultan Kılıç Arslan II, as "The Second Sulaymān"65 and the depictions on the surviving tilework in the mina'i technique from the Kılıç Arslan II köşküpavillion in Konya suggest that the representation of the four armies of the Prophet Sulaymān may also have formed the subject matter of this earlier palace tilework. It was possibly also combined with references to the Shahname, the combination of allusions to the ruler Sulaymān and to the legendary rulers of Iran thereby emphasising to contemporaries Sultan Kılıç Arslan II's claim to be the Just Ruler of the Age, through the figures depicted on the mina'i painted tilework of the Konya köşk. During the period from 1205 to 1246, that is, from the second reign of Sultan Giyath al-Dīn Keyhusrev I (r. 1205-11) 66 $^{6}$, through the reigns of: Sultan 'Izz al-Dīn Keykavas I (r. 1211-20) ${ }^{67}$, Sultan 'Ala' al-Dīn Keykubat I (r. 1220-37) ${ }^{68}$, Sultan Giyath al-Dīn Keyhusrev II (r.

55 Browne 1997, 113.

56 Bosworth 1977, 89.

57 Bosworth 1977, 91.

58 Browne 1997, 396.

59 wârit-i mulk-i Sulaymân. Sâdi 1974, 6, 15; Blair - Bloom 1995, 23; Mottahedeh 2013, 256.

60 Ravendi I, 1999, 135; 261, 263. As likewise for example when Ravendi describes the Seljuk sultan Giyath al-Dīn Keyhusrev I as possessing the nature of Sulaymān, "Süleyman huylu" with the morals of Khosrow I (Anurshirvan the Just), "Nurşivan ahlaklı" the justice of the second Caliph Umar, "Ömer adaletli" the virtue of Cyrus the Great (559-529 B.C.), "Keyhusrev faziletli" with people and jinn under his command, "insanlar ve melekler onun buyruğu altına giriyorlar" dedi". Ravendi 1999, II, 423. The Persian edition of Ravendi's text by Muhammed ikbal of 1921, was translated by Ahmet Ateş and published by the T.T.K. It is unknown for a temporal ruler to exercise control over the angels (melekler). The Persian edition has in fact the word Peri, meaning in this context jinn, not melekler, as given by Ahmet Ateş. I thank Mahmut Demir M.A. for his assistance in the checking of the Persian text.

61 Ravendi I, 1999, 85, “...ve insanlar, şeytan (Jinn), peri (Jinn), hayvan ve kuşlar Süleyman gibi”.

62 Rūm as is recorded in the Surat Ar-Rūm (The Romans) - ال روم سورة - hence, Malik ar-Rūm - Ruler of the Romans = the East Roman Emperor, eg. Usama 2008, 11, fn. 6, distinct from the Sultan ar-Rūm. While C. E. Wilson in 1924 relates of the word Rūm, "It is now applied by the Persians to the Ottoman Empire", Nizami 1924, II, 151, commentary on line, $546 ; 1,473$.

63 Bibi 1996, I, 20; 79.

64 Ravendi describes him, "Süleyman Peygamberin mülkü Süleyman'a geldi, Iran ve Turan'a müjdeler ulaştı" Ravendi I, 1999, 44.

65 Bibi 1996, 79.

66 Bibi 1996, 89-90.

67 Bibi 1996,181. Described by Ravendi as possessing the nature of Suleyman, "Süleyman huylu" Ravendi 1999, II, 423. 
1237-46), with his first wife from Georgia described as, like "Belkis," the wife of the Prophet Sulaymān-Solomon $^{69}$, in the surviving literary record, each of these Rūm Seljuk Sultans were described by the laqub "The Second Sulaymān". Echoing and maintaining this association, The Second Sulaymān was also a lakab-laqub used by Osman Gazi ${ }^{70}$ and by other Turkish rulers ${ }^{71}$ including unsurprisingly, Sultan Kanuni Süleyman $\mathrm{II}^{72}$, and it was this association between the Prophet Solomon-Sulaymān and this Ottoman Sultan that, in part, resulted in the extensive renovation and restorations conducted in al-Quds-Jerusalem, the second sacred site in chronological order in the Islamic world and the direction of the first qibla, by this Sultan ${ }^{73}$. As Sylvia Auld remarked, the association of "above all Solomon, with the site, lasted at least until the $17^{\text {th }}$ century, for in A.D. 1672 Evliya Çelebi described the Mosque as having been founded by King David and completed by Solomon, who had been helped by rebellious jinn. These he had controlled by means of a talisman; when they were not working, Solomon had been forced to keep them imprisoned in the vaults under the mosque (popularly known today as 'Solomon's Stables' $)^{\prime \prime 74}$.

The use of titles naming the Prophet Dhū'l-Qarnayn, "The Second Dhū'l-Qarnayn/ Zhü'lQarnain/Alexander," or "The Alexander of the Age"

Alexander the Great in the Islamic World was understood to have ensorcelled, to have exercised control over, an army of djinns and forced them to build a giant iron and brass barrier-gate between the Breasts of the World (or Breasts of the North ${ }^{75}$ ) to defend the civilised world from the forces of Gog and Magog ${ }^{76}$. Annemarie Schimmel has suggested it was on account of Alexander providing a barrier to the forces of Gog and Magog that a ruler would be described as the second Alexander ${ }^{77}$. Alexander was educated to be the Just Ruler by Aristotle, the translation of whose works underlay Abu Nasr al-Farabi's $X^{\text {th }}$ c. educational syllabus of the philosopher-king, and Alexander-İskander was understood as being a figure of the Just Ruler in the Islamic world. He is also said to have had a meeting with the King of the Jinn on Mount Qaf, recorded in the earliest Arabic accounts of the Alexander Romance dating from the $\mathrm{VII}^{\text {th }}$ and VIII' ${ }^{\text {th }}$ centuries A.D. by Wahb ibn Munabbih, c. 680 and by 'Umara ibn Zaid 767-815' ${ }^{78}$ and, in

68 Bibi 1996, 232, 238, n. 596. This title is also recorded on the coins of the Artukid ruler, Artuq Arslan minted in Mardin in the name of this Rūm Seljuk Sultan in h. 632, 633, 634/1234-1237.

69 Bibi 1996 II, 37.

70 Lowry 2012, 85, "the second Süleyman, Gazi Paşa".

71 In Mughul India, Jahangir (1605-27) and then Shah Jahan I Khusraw (1628-57) were celebrated as being the

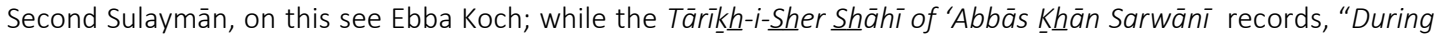
the period of the rule of Jalal al-Din Muhammad Akbar Badshah the second Sulaymān in 975 A. H."; while John Chardin records of the Safavid ruler of Iran, that his tent, called the House of Gold, carried an inscription on the cornice in the antechamber that described it as the Throne of the Second Sulaymān, and the Safavid Shah, Safi II (1666-1694) was re-enthroned in 1668 as Sulaymān I.

72 "Dated 933 (1527), it refers to the universal monarch as "our master, the great sultan, the second Solomon in world sovereignty, son of Sultan Selim Khan, the amir of the amirs of the Arabs and the Persians". Süleyman subsequently renovated the Pools of Solomon and the aqueduct for the water channel of his own charitable fountains, which he built in 943 (1536-37)". Lowry 2012, 85, together with the major works of restoration at alQuds/Jerusalem on the haram, including the restoration of the Dome of the Rock.

73 "poetical and Koranic inscriptions on weapons for Sultan Süleyman the Magnificent's armory show that he certainly felt himself heir to the prophet-king's glory" Schimmel 2014, 74.

74 Auld 2005, 56.

75 Stoneman 1991, 186.

76 Qur'an Al-Kahf, 19: 92-97.

77 Schimmel 2014, 116. For reference to the Turks and Alexander see R. Şeşen, Eski Arablar'a göre Türkler, 11-36, 31.

78 Zuwiyya 2011, 81. 
consequence, there was the association in the use by rulers of this name-title - of justice, of protection against the forces of chaos, and of exercising control over the Jinn. In an $\mathrm{XI}^{\text {th }} \mathrm{c}$. iskandarnameh, ìskandar is said to have had an affair with and married Arāqīt, a Jinnee Queen ${ }^{79}$, thereby paralleling the relationship between Sulaymān and Queen Belkis, suspected by some of being a half-Jinnee ${ }^{80}$; while in the Alf Laylah wa layla-The Thousand Nights and One Night, in Night 464 is a tale of Iskander-Dhū al-Qarnayn, which is also related in Abū Hāmid Muhammad ibn Muhammad al-Ghazālì's Nasīhat al-muluk ${ }^{81}$ c.1105-1111 ${ }^{82}$, a work which also has a tale concerning the King Solomon and the Angel of Death. The example of the Just Ruler exercising control over and employing the Jinn and, in the case of both Sulaymān and Alexander, it was formerly well understood that the Just Ruler was in a relationship with a Jinnee, a female jinn.

Ebû Bekr Necmüddîn Muhammed b. Alî b. Süleymân er-Râvendî draws the parallel at times between Seljuk rulers and the Prophet Süleyman and İskander and Keyhusrev-Jamshid: "The real Süleyman is this ruler, because his reign was bequeathed to him by Süleyman. Süleyman had the ring, you have the saddle; Alexander had the mirror, you have the law! What you've seen as fate, Alexander had seen in the mirror, Keyhusrev in the cup" ${ }^{\prime 83}$. That is, what the Seljuk Sultan (the Just Ruler of the Age, like Alexander and Keyhusrev-Jamshid ${ }^{84}$ ) saw of fate, Alexander saw in the mirror on the Alexandrine Pharos, as that which Jamshid saw in his cup, (as that which Adem-Adam saw in the mirror given to him by Allah ${ }^{85}$ ), meaning this Seljuk Sultan was to be understood as the Sulaymān -Alexander - Keyhusrev - Jamshid of the Time, that is, the Just Ruler. He writes: "He on the throne of Süleyman drank the water of life like Hızır, he dispatches armies like Alexander; what else could he desire?"86 Ebû Bekr Necmüddîn Muhammed also describes Sultan Malikshah as like İskender-Alexander ${ }^{87}$, while Sultan Sanjar b. Malikshah was described by Sayyīd Eşref as fathered by the Second Alexander ${ }^{88}$, fathered by Sultan Malikshah;

79 Southgate 1978, 160-161.

80 As noted by Stoneman 2012, xI; Venetis 2007, 227, 229. The XI ${ }^{\text {th }}$ C. Qișaș al-anbiyä', Ahmad ibn Muhammad alTha'labī al-Naysābūrī relates, "One of the parents of Bilqīs was a jinnī". Brinner 2002, 523; and that work of the same name by Muḥammad ibn 'Abd Allāh al-Kisā'ī relates that Ruha, daughter of Shalsael son of Jaan, bore twins, first Balaqis and Qutruba, and then Faqtas and Faqtasa, and the association may also stem from the resemblance of Balqis to the name of the jinnee, Balaqis. However, Ibn Arabi relates: "Now let it be known like this, that some have said that Bilqīs is the daughter of Sharakhil from the descendants of Ya'arab bin Qahtān, and Sharakhil was a very great king (ruler). He married a woman of the jinn who used to be called Rayhāna bint AsSukun. Thus Sharakhil had no other children except Bilqis". "The Shayk, may God be pleased with him, in his Tarjumān al-Ashwāq, says that Bilqīs was born between Man and jinn. If her father had been of mankind and her mother from the jinn, she would have been dominated by the spirituality". Arabi 1991, 763. Likewise, Arabi 1978, 50. There is an early $\mathrm{XIV}^{\text {th }}$ c. miniature of this subject, including the hairy feet of the queen, File:Balami Tarikhnama - Bilqis crosses the pool covered by crystal to ...https://commons.wikimedia.org/.../File:Balami__Tarikhnam... (In the $\mathrm{XV}^{\text {th }}$ c. Muḥammad ibn Khāvandshāh in his The Rauzat-us-safa, Or, Garden of Purity: Containing the Histories of Prophets, Kings, and Khalifs, relates that Rihana daughter of Sakan, the King of the Jinn, gave birth to Belqis).

81 For the matter of authorship, see: Khismatulin 2015

82 Yamanaka-Nishio 2006, 103-105.

83 Ravendi I, 1999, 135, "Hakiki Süleyman bu hükümdardır, çünkü hukümdarlıkla ona Süleyman'dan yadigar kalmıştır. Süleyman'ın yüzüğü vardı, senin eğerin var; İskender'in aynası vardı, senin kanunun var! Senin felekten gördügünü iskender aynada, Keyhusrev kadehye görmüştü!".

84 Mousavi 2012, 84.

85 Al-Qaddūmī 1996, 175.

86 Ravendi I, 1999, 188, "Süleyman'ın tahtı üzerinde, Hızır gibi -ab-ı hayat içmiştir; iskender gibi ordu sevkeder, isteyecek neyi kalmıştır?".

87 Ravendi 1999, II, 244.

88 Ravendi 1999, II, 296, "ikinci İskender babası". 
while Muhammad Mirhand described Mesut b. Muhammad b. Malikshah as possessing both the beautiful justice of Alexander and the munificence that distinguished Khusrev-Kisra ${ }^{89}$.

In the early XIII ${ }^{\text {th }}$ c. Taj Al-din Hassan b. Nizāmī Nishapurī in his history of the period from 1191-1219 entitled Tāj al-ma'āthîr refers to the future Delhi Sultan Shams al-Dīn Iltutmish (1211-36), for defeating in battle the armies of disbelief, as the Second Alexander - iskandar-i Sān $\imath^{-90}$; while at about the same time, the Ghurid Mu'izz al-Dīn Muhammad 1173-1203 is described on the Kutb Minar as Iskandar al-Thanī, this title was echoed by 'Ală'-al-Din Muhammad Shah, (1296-1316) Khalji, in his inscription on the incomplete Alai Minar in Delhi of c. 1315, that, this building was constructed during the reign of the magnificent sultan 'Ala-u'd-Dunya wa'dDin, the second Alexander, the right arm of the caliphate, Abu'l- Muzaffar Muhammad yamin al khilafat and Sikandar al-'Ahd wa al-zaman (The Alexander of the age), a title which is also recorded on his coinage, Sikandar al thani, Yamin al Khilafat "the Second Alexander, The right Arm of the Caliphate", for keeping the Pagan Mongols, by some at the time regarded as the forces of Gog and Magog, out of India.

On the inscription-kitabe of the Taş Medrese in Egirdir of 1237-8, not only is the the Rūm Seljuk Sultan Giyath al-Dīn Kayhusrv II described as the Second Alexander ("Iskandar al-thani") but also as "Dhü'l Qarnayn al-Zaman"91, literally the "Dhū'l Qarnayn of the Age" using the Koranic name understood to indicate Alexander, Dhū'l Qarnayn/Zul-Qarnain, of Qur'ān Al-Kahf 18:83-98, thought at that time to be Alexander the Great, as the tafsirs and experts agreed; Ibn Hisham was probably the first (c. 800), but tafsirs from the $X^{\text {th }}$ century onward all reach the same conclusion, Dhū'l al-Qarnayn was to be associated with Alexander - al-Iskandar al-Rūmī who was sent by God to the East and the West to subdue the peoples of the World, calling them to the monotheistic faith. David Zuwiyya writes of the matter as to if Dhū al-Qarnayn was a Prophet, or was to be described as wali Allah - "friend of God," that, "Al-Tabari, a ninth-century author, reflects the dichotomy surrounding the Macedonian conqueror by narrating Dhulqarnayn's life and deeds in his Tafsir, an exegetical study of the Quran, and Alexander's story in his Ta'rikh [annales], an historical work"192. Likewise, on the kitabe of Incir hanı by Bucak, Antalya, of 12381239 the Rūm Seljuk Sultan Giyath al-Dīn Kayhusrv II is also described as the "Second Alexander," and also as "Dhüll Qarnayn al-Zaman"93. The use of both of these names on these kitabe was surely of considerable significance at that time, given the looming threat posed by the Pagan Mongols. (There is perhaps also the possibility that the use of these names in these public inscriptions at this time may also have had importance in the context of the relationship between the Rūm Seljuk Sultan Giyath al-Dīn Kayhusrv II and the forces of the Khwarazm Shah after the battle of Yassiçimen of 1231 and the murder of the Khwarazm Shah Jelāl al-Dīn Magubertī, as, at the time these kitabe were inscribed there was the attempt to incorporate Khwarazm forces into the Seljuk state, and it was the case that these were the same titles as Jelāl ad-Dīn's father, the Khwarazm Shah 'Ala' al-Dīn Muhammad II b. Tekish (595/1200 to 517/1220), who had the titles "Iskender-i Sânī - Iskander Zu'I-Karneyn II" the Second Alexander, the Second Zu'l Karneyn) after the capture in battle of Tayanku and, in consequence of this title of h.607/1210-11 ${ }^{94}$, he was regarded as equal to the Great Seljuk Sultan Sanjar, who also had

\footnotetext{
39 Mirhand 2015, 204, “iskenderin güzel adetlerine ve Kisra'nın cömertliklerine uyarak temayüz etti”. 
the title İskender-i Sâni ${ }^{-95}$. Likewise the name of the dedicatee of a qasidah written by Saiyid Abu 'Ali b. al-Husain al-Marwazi, which 'Aufï records, designated this Khwarazm-shah as, 'Sultan Iskandar ${ }^{96}$ ).

There is of course no reason to suggest on the basis of references to İskander in Rūm Seljuk inscriptions and in contemporary texts, and the re-use of ancient buildings and ancient sculptures and carvings in Rūm Seljuk territory, "that the Rum Seljuqs identified themselves with the glory of Antiquity" ${ }^{\prime \prime}$. Antiquity was of course, associated at that time with Paganism- Jahilliya, The Age of Ignorance (prior to Islam); while the İskandar-Alexander of the Muslim world was a proto-monotheist, not a polytheist Pagan, he was a warrior for the faith, the destroyer of polytheists, of idolatry, and, as pointed out by the poet Abu'l Hasan Ali ibn Julugh Farrukhi Sistani (d. 1037) in respect to comparison between Alexander and Mahmud of Ghazna, "The tale of Alexander has become an antique myth" ${ }^{98}$, and Ali Anooshahr writes Farrukhi "focusses most of his subsequent attack on the 'antiqueness' of these stories, which have now been outdone by the reigning Emir Mahmud" ${ }^{\prime \prime}$. It was doubtless likewise the case that Rūm Seljuk rulers thought they had surpassed 'Antiquity,' as they, like Sultan Mahmud, were on the frontier, identified themselves as proud possessors of monotheistic Islam, of their titles and banners from the Caliph and were confident users of the remains from antiquity, antiquity posed no threat, Paganism had been surpassed, the remains from antiquity could be converted for re-use, not least displayed to exhibit the power of the religion over the 'antique,' over the remains from the Jahilliya.

Later the Mamlūke Sultan Baybars was styled the 'Alexander of the Age' (Iskandar al-zamān) between 1266 and 1270, and in each case the rhyming formula was used: Iskandar al-zaman fâbib al-qiran, "Alexander of the time, Lord of the favourable conjunction", as on Baybars' inscription on the restored mausoleum of the Sword of Islam, Khalid b. Al-Walid, at Hims, Syria ${ }^{100}$. The use of this title was doubtless, as with the earlier Rūm Seljuk usage, employed in drawing attention to the threat posed by the Pagan polytheist Mongols. The Mamlūke Sultan Khalil b. Qalawun was also described as Iskandar al-zaman ${ }^{101}$ and this title was regularly given to Mamlūke Sultans as recorded by al-'Umari in the $\mathrm{XIV}^{\text {th }}$ C., and copied by al-Qalqashandi in his Subh al-A'sha completed in 1412. ${ }^{102}$ Sultan Ala al-din Ali Shah (742-746; 1341-1345) ruler of Lahhnawti is described on his coinage as "Iskandar al-Zaman" and on the reverse, "Sikandar al-Zaman alMakhfu"103, Alexander of the Time, the Hidden. While legend records Timur at his birth was know to be a second Iskander due to the fact that it was said to have been stated by Aristotle that 800 years after the birth of Alexander would be born the Prophet of Islam and 800 years after the Prophet's birth, "a second Alexander"104 hence also, fâbib al-qiran, Lord of the favourable conjunction, a title belonging to İskander-Alexander and Dhū al-Qarnayn, and to Timur. Sultan Mehmet II the Conqueror, called himself the "Second Iskandar" and was so

95 Kurpalidis 1993, 134. He suggests it was because both Sanjar and the Khorezmshah were great warlords that only these Oriental rulers assumed the name of the great warlord of antiquity, but this fact of being a warlord, was probably not the only, nor the primary reason for the adoption of this title by these rulers. http://manualzz.com/doc/34036657/the-age-of-achievement--ad-750-to-the-end-of---unesdoc

Met 2016, 82.

98 Anooshahr 2009, 70.

99 Anooshahr 2009, 71.

100 Hillenbrand Crusades 1999, 230. See also, Aigle 2009, 7. https://hal.inria.fr/docs/00/38/33/36/PDF/Baybars.pdf.

101 Hillenbrand Crusades 1999, 231.

102 Hillenbrand Crusades 1999, 232.

103 Karim 1960, 39.

104 Sela 2011, 64, 68; citing from Sharaf Yazdī's Zafa-nāma, with the conjunction of the stars in Capricorn. 
described by contempories such as Tursun Bey ${ }^{105}$ and Michael Kritovoulos ${ }^{106}$, and this title continued to appeared on Ottoman official documents into the $17^{\text {th }} \mathrm{c}^{107}$ Sultan Selim following the battle of Çaldıran in 1514 was described as iskender-i Sâni $i^{108}$ while both of these titles, "the Second Solomon" and "the Alexander of the Age," formerly employed by the Seljuk Sultan Giyath al-Din Keyhusrev II, appear on the endowment deed for the Suleimaniye mosque of Sultan Süleyman Kanuni ${ }^{109}$ and this expressed reality was reinforced it seems through the import of columns from Baalbek, said to have been built, like Tadmor/Palmyra, by order of the Prophet Sulaymān and the Jinn ${ }^{110}$. and also of columns brought from Alexander's city of Alexandria-Iskanderiyya, Misr/Egypt, which were employed in the construction of this mosque in the $16^{\text {th }} \mathrm{c}^{111}$.

S. Lloyd and D. Storm Rice in 1958 wrote in reference to the lakab Khusrev: "Khurev stands for Khusev Irān or Khusrev zamānihi and has no political significance. It is a purely honorific appellation which several rulers arrogated to themselves, claiming comparison with Chosroes I, whose legendary sense of justice they were pretending to emulate" ${ }^{\prime 112}$, indicating this lakab was an empty title. This sentiment was echoed more recently by J. M. Rogers in respect to a rarer title recorded in S. Lloyd and D. Storm Rice's Alanya ('Alā'iyya): "and then, probably after 626/1228-9 the even more grandiloquent title of qasim amir al-mu'minin (equal partner), on what grounds we do not know. Too close a reading of such inscriptions runs the danger of unhistorical conclusions, and it is significant that since Rice wrote this classical approach has rather fallen into neglect ${ }^{\prime \prime 13}$. However, it seems to have been the case that rather than any pretended emulation, empty honorific or obscurity of a title granted on unknown grounds, concerning these two titles, firstly the lakab, qasim amir al-mu'minin from its distribution by the Abassid Caliph in the $\mathrm{XII}^{\text {th }} \mathrm{c}$. largely to Turkish rulers on the periphery of the Islamic world where there was jihad, in Northern India, as in Anatolia, including Sultan Alaed-Din Keykubad's 1225 campaign against Lesser Armenia, placing it under tributary status and conquering its western region eastwards to Silifke ${ }^{114}$, it seems probable that this title was given by the Caliph for expanding through jihad the territory under Islamic control and for defending Islamic territory. While, secondly, the lakab of Khurev, like the Second Sulaymān, the Sulaymān of the Time/Age, the Second Dhū'l al-Qarnayn, the Dhū'l al-Qarnayn of the Age/Time and the Second Alexander, the Alexander of the Time/Age, was at that time, as subsequently, quite simply understood as being a reference to, and a reminder of, the claim to, and of the stated aim of the Sultan with this lakab to be known as the Just Ruler, as Hasan ibn Ali of Tus, Nizam al-Mulk had indicated in the opening of his Siyar al-Muluk, so that the inhabitants of the realm were reminded that it was, "under his just rule they may live their lives in constant security and ever wish for his reign

105 Bağcı 2005, 437, Cat. No. 239.

106 Bağcı 2005, 437, Cat. No. 239.

107 E.g., Kármán-Kunčević 2013, 407, "the 'ahdname given to Gabor Bathory in 1608: "ben-ki sultanu selatin-i şark u garb sahib-kiran-i memalik-i Rum ve 'Acem ve 'Arab tac-bahş-i husrevan-i cihan zıllu llahi I-meliki I-mennan sani iskender zu I-karneyn hadimü I-harameyniş-şerifeyn hafiz-şi'arü kıbleteyn eşrefi I-medayin ve-I emsar ve akdasu memalik ve-l aktar".

108 Cipa 2017, 236

109 esnä-i selätinda Süleymän-i säni ve iskender-i düvum ve häkän-i havakin-i evreng-i heftümdür.

110 Mottahedeh 2013, 249.

111 Baker 2004, 191.

112 Lloyd-Rice 1958, 66

113 Rogers 1998, 376.

114 Duggan 2011. 
to continue ${ }^{115}$. In consequence it can be understood that these were most certainly titles of some political significance in Islamic terms, one seems to have been a marker of the ruler at the frontier, of jihad; while the other group of titles reflected the longstanding, extensive and important work undertaken by both theologians and others in their written works on Just Rule, as a model for rulers in the Islamic world from the $\|^{\text {nd }} / \mathrm{VIII}{ }^{\text {th }} \mathrm{c}$. onwards, and a rulers' explicit interest, in realising through emulation, the ideal of the Just Ruler. Both were titles that found expression not only in written texts, but in the visual language of design employed on state structures.

\section{Part III}

\section{The Proximity of the Jinn}

The Qur'ān makes repeated reference to the Jinn from al-Fatiha onwards, "Lord of all beings": that is, of all creatures, the jinn, mankind, animals and birds" ${ }^{116}$, "I did not create jinns and human beings except to worship me"117. "We have created many jinn and people for hell; they have hearts which they do not understand, they have eyes with which they do not see, they have ears with which they do not hear"118. "I seek refuge in the Lord of mankind...From among the jinn and mankind"119. "And [also] the devils [of jinn] - every builder and diver. And others bound together in shackles"120. While the matter of collusion between Jinn and humans was a possibility itself suggested in the Qur'an, concerning its unique eloquence: "Were all of humankind and the Jinn to assemble for the purpose of bringing the likes of this Qur'an, they would not bring forth its counterpart, even if they colluded intently"121. Both majnūn, meaning possessed by a jinn, and, jinna, meaning possession by a jinn, are also words mentioned in the Qur'ān. The Qur'ān also records the Prophet of Islam recited parts of the Qur'ān to the Jinn as well to people: "Say (O Muhammad): "It has been revealed to me that a group (from three to ten in number) of jinn listened (to this Qur'ān). They said: 'Verily, we have heard a wonderful Recitation (this Qur'ān)! 'It guides to the Right Path, and we have believed therein, and we shall never join (in worship) anything with our Lord (Allah)"122. As likewise, "And (remember) when We sent towards you (Muhammad) a group (three to ten persons) of the jinn, (quietly)"123. A modern mosque in Mecca is called the "Mosque of the Jinn" which stands upon the site of an oratory where the Jinn, the people of the subtle world, are said to have come and pledged their loyalty to the Prophet ${ }^{124}$.

A hadith qudsi states: "O My servants, if the first of you and the last of you and the mankind of you and the jinn of you were to stand in one place, then to ask of Me, and I were to give to each of you everything he asked, that would not diminish My kingdom by anything, any more than a needle dipped into the sea would diminish the sea".

It is related that 'Abdullah bin Mas'ud (may Allah be pleased with him) narrated: "A man

115 Op. cit. fn. 20.

116 For this understanding, see for example Renard 1998, 29-34, giving examples from the VIIIt to the $16^{\text {th }} \mathrm{C}$.

117 Qur'an Adh-Dhariyat, 51: 56.

118 Qur'an Al-A'raf, 7: 179

119 Qur'an An-Nas, 114:6.

120 Qur'an Sad, 38:37-38.

121 Qur'an Al-Isra, 17:88.

122 Qur'an Al-Jinn, 72: 1.

123 Qur'an Al-Ahqaf, 46:29-30. For an example of preaching with this text in the late $20^{\text {th }}$ C., see, Gaffney 1994,170

124 Glassié-Smith 2003, 132. 
from among the humans went out and was met by a man from among the jinn, who said: "Will you wrestle with me? If you throw me to the ground I will teach you a verse which, if you recite it when you enter your house no devil ${ }^{125}$ will enter". So the man from the humans wrestled with him and threw the jinn to the ground. He (man from the humans) said: "I see that you are very small and your forearms are like the front paws of a dog. Are all the jinn like this, or only you?" He (the jinn) replied: "I am strong amongst them. Let us wrestle again. "So they wrestled again and the human again threw him to the ground. So, the jinn said: "Recite Ayat al-Kursi (Surah AlBaqara, Verse 255), for no one recites it when he enters his house except that Shaytan leaves, passing wind like a donkey". "It was said to Ibn Mas'ud (may Allah be pleased with him): "Was that man "Umar ibn al Khattab?" (may Allah be pleased with him). He said: "Who else could it have been, other than "Umar?" (may Allah be pleased with him)"126. Malik ibn Anas records, "Malik related to me that he heard that 'Umar ibn al-Khattab wanted to go to Iraq, and Ka'b alAhbar said to him, "Do not go there Amir al-Muminin. Nine-tenths of sorcery is there and it is the place of rebellious jinn and the disease which the doctors are unable to cure" ${ }^{\prime 127}$. He also related, "Yahya related to me from Malik from Nafi' from 'Abdullah ibn 'Umar that some men from Iraq said to him, "Abu 'Abd ar-Rahman, we buy the fruit of the palm and the grape and we squeeze them into wine and sell it. 'Abdullah ibn 'Umar said, I call on Allah and His angels and whatever jinn and men hear to testify to you that I order you not to buy it nor sell it nor press it nor to drink it nor you give it to people to drink. It is something impure from the work of Shaytan"128.

of the Jinn played a political role in the VIII ${ }^{\text {th }} \mathrm{c}$. in the Alid propoganda circulated after the overthrowal of the Omayyad Caliphate (itself associated in part with a major earthquake after that of 659 that struck Jerusalem and destroyed the al-Aqsa Mosque in 749 A.D.) which was read as a sign of the Almighty's lack of support for the Omayyad Caliphate, of an "apocryphal hadith that supported the belief that certain malevolent demons that the Prophet - King Solomon (Sulaymān) had banished to islands in the sea, would be released in the year $h$. 135/752-3 A.D. and that they would come to Syria and Iraq in order to ignite theological discussions there... this element of the Solomon legend was widely disseminated" ${ }^{129}$.

Ibn Sa'd transmits a report on a meeting between Tamin bin Aws al-Dārī (d. 661) from the Banu Lahm tribe, a Christian hermit or monk, and jinns in a ravine in Syria. The jinns informed him that the Prophet had appeared in Arabia. Following this news from the jinn Tamin travelled and met with Muhammad and converted to Islam and became min alsahaba ('one of the friends' of the Prophet Muhammad) in Medina. Concerning the tales related of Sahābi Tamìm al-Dārī; it was later said he was carried away by jinn to islands in the surrounding ocean, to the lost city of many-columned Iram or to the barrier of Gog and Magog constructed by the Jinn working for Dhü'l al-Qarnayn and he was only freed in consequence of a battle fought between the believing and the unbelieving Jinn ${ }^{130}$.

Tabarī records from his VII ${ }^{\text {th }}$ c. source, M. b. Ibn Ka'b al-Qurazi: "We have heard that Solomon's army [stretched) one hundred parasangs: twenty-five of them consisted of humans,

125 Meaning jinn, as in, Qur'an Sad, 38:37-38, “And [also] the devils [of jinn] - every builder and diver And others bound together in shackles".

126 Al-Mu'jamul Kabir, Hadīth: 8824 and 8826. Cited Renard 2014, 28.

127 Anas 2013, 410, 54:11.30 Concerning the East.

128 Anas 2013, 42, 42:5.15, General section on Wine being made Haram.

129 Van Ess 2016, 294, fn. 21.

130 See for example, "The Story of Tamim al Dari" in, Jayyusi 2012, 253-262. 
twenty-five of jinn, twenty-five of wild animals, and twenty-five of birds"131. And that, "When Solomon was faced with something he did not know, he began by asking humans about it. If humans had knowledge of it, [good], otherwise he asked the jinn. If the jinn had no knowledge about it, he asked the demons ${ }^{\prime \prime 132}$.

Masudi in his muruj al-Dhahab, Meadows of Gold, of 947, relates the Caliph Mu'tadid (279289/892-902) was repeatedly beset in his palace by an apparition, who was thought by some to be a member of the believing Jinn ${ }^{133}$.

In the XI ${ }^{\text {th }}$ c., Abū Ishāq Ahmad ibn Muhammad ibn Ibrāhīm al-Tha'labī al-Naysābūrī (d. 427 A.H.-1035), related in his Arā'is al-Majālis fi qisas al-anbiyā, quoting Tabarī, that, "Solomon had an army of 100 parsangs in extent; one quarter men, one quarter Jinn, one quarter beasts, and one quarter birds"134. He also related that the Prophet Sulaymān's throne was fashioned by Sakhr the jinni ${ }^{135}$ and he related an account similar in its content to that given by 'Abdullah bin Mas'ud, above: "Ismā'îl b. Muslim-Abū Mutawakkil al-Bāji-Abū Hurayrah who had the key to the house of charity in which there were dates. One day he went there and opened the door, and behold, a handful of them had been taken. He went there on another day and again the same amount had been taken. Again he went there another day and a similar amount had been taken. Abū Hurayrah mentioned this to the Prophet, who said to him: "Would it make you happy to seize him?" He said: "Yes". He said: "When you open the door, say: 'Praise be He who subjected you to Muhammad."' So he went and opened the door and said this, and behold, (the thief) stood before him. He said to him: "Enemy of God, are you the perpetrator of this deed?" He said: "Yes". Then said: "I shall not come again (i.e. do it again). So (Abū Hurayrah) let him go. He went back and mentioned this to the Prophet, who said: "Will it make you happy to seize him?" He said: "Yes" (The Prophet) said: "When you open the door, say the same thing again. He opened the door and said, "Praised be He who subjected you to Muhammad" And behold, (the thief) was again standing before him, so he said to him: "Enemy of God, did you not promise me that you would not come back again?" He said: "Let me go just this time and I shall not return". So he let him go. Then he returned and seized him a third time and said: "Did you not promise me that you would not come back? I shall not let you go today before I bring you to the Prophet". He said: "Do not do that! If you let me go, I shall teach you a phrase which, when you say it, will (let) no jinnï"come near you, neither small nor large, neither male nor female". He said: "Will you really do that if I let you go?" He said: "Yes". He said: "Then what is it?" He said: "Allah, there is no god but He the living, the Eternal One..." (2:255) until he had completed the verse, then he let him go. (The thief) did not return thereafter. Abū Hurayrah mentioned this to the Prophet, who said: "Did you not learn this, Abū Hurayrah, such is the truthfulness of evil ones?"136.

Abū Ḥamīd bin Abū Bakr Ibrāhīm Nīsābūrī, Farid ud-Dīn Attar (1145-1220) begins his work on the spirits' difficult return journey from this world to the Truth by introducing the Guide:

"Dear Hoopoe, Welcome! You will be our guide;

It was on you King Solomon relied

131 Ṭabarī 1985, III., 154.

132 TTabarī 1985, III., 161.

133 Mas'udi 1989, 360.

134 Mottahedeh 2013, 248.

135 Brinner 2002, 512. This jinn is said by some to have taken the Prophet Sulaymān's seal ring and occupied his throne for forty days, before dropping it into the sea.

136 Brinner 2002, 26. 
To carry secret messages between

His court and Sheba's lovely queen ${ }^{137}$.

He knew your language and you knew his heart-

As his close confidant you learnt the art

Of holding demons (unbelieving Jinn) captive underground,

And for these valiant efforts you were crowned" ${ }^{\prime 38}$.

Farid ud-Dīn Attar recording that as the confidant of the ruler, Sulaymān-Solomon, the Hoopoe was able to exercise control over the unbelieving Jinn and for this, as also for purveying secret messages, the Hoopoe was crowned.

Muhyiddin Muhammad b. 'Ali Ibn 'Arabi (1165-1240) in his Fusus al-Hikam of 627/1229, in the Chapter entitled, The Wisdom of Compassion (al-hikmat ar-rahmaniyyah) in the Word of Solomon, provides a description of the nature of the jinn: "Let it be known like this, that the jinn are strong spirits, and they are subtle and corporeal bodies. They are under the dominion of the jewel of fire and air. We (humankind) are under the domination of the jewels of earth and water. The elements of earth and water are heavy elements. Because of the strength of their spirits and the subtleness of the jewels of their bodies, God has given them power to appear in different forms, and like the quick action of the angels they are established with actions beyond the ability of Man. Only this much is different, that the spirits of the jinn are lower spirits and the angels are heavenly spirits" ${ }^{\prime \prime 139}$.

Ibnu'l-Farid (1181-1234) also mentions them:

"And apparitions strange

Of naked viewless spirits thou mayest espy,

That wear no friendly shape of humankind,

For genies (Jinn) love not men"140.

It is related in the Manqabat by Muhammad Talqānī that Shaykh Amir Sayyid 'Alī ibn Shihāb alDìn Hamadānī (1314-1385) converted the population of 'Alīshāh in Khuttalān through causing the repentance of a great lion and the repentance of a group of jinn in human form ${ }^{141}$ who then promised to not harm anybody, which enabled people to pass through these parts. He also converted a jinn in human form from unbelief ${ }^{142}$.

From the above recorded examples it seems evident that the proximity of Jinn and human beings was an understood part of the world view of Muslim populations from the wood-cutter and servant, to the educated, and Emir, Sultan and Caliph.

\section{Their Appearance}

The Qur'an relates, Sād 38:34: "And, indeed We did try Sulaiman (Solomon) and We placed on his throne Jasadan (a jinn-devil, so Sulaiman lost his kingdom for a while) but he did return (to his throne and kingdom by the Grace of Allah and he did return) to Allah with obedience and in repentance ${ }^{143}$, a passage recording the Jinn take human form, as noted above in respect to the

137 Qur'an Al-Anbya, 21:20 "Solomon inspected the birds and said, 'Why do I not see the hoopoe? Is he absent?"

138 Attar 1984, 1.616-613, 29.

139 Arabi 1991, 785.

140 Nicholson (1921) 1980, 190-191.

141 De Weese 1999, 150.

142 De Weese 1999, 150.

143 Qur'an, Sād 38:34, Picthall, "And verily We tried Solomon, and set upon his throne a (mere) body. Then did he repent". Qur'an, Sād 38:34, Muhsin Khan "Sulaiman (Solomon) and We placed on his throne Jasadan (a devil, so 
Prophet preaching to the Jinn of of Nișībīn. Edward Lane relates from numerous Prophetic hadīth that: "The Jinn are of various shapes, having the forms of serpents, scorpions, lions, wolves, jackals etc. The Jinn are of three kinds - one on the land, one on the sea, and one in the air. The jinn consist of forty troops, each troop consisting of six hundred thousand. The Jinn are of three kinds - one have wings and fly; another are snakes and dogs; and the third move about from place to place like men. Domestic snakes are asserted to be jinn on the same authority"144. It is reported that Jinn can take the form of animals/Jinn can live in animals, particularly black animals, and so if a person harms an animal, particularly at night, these can be jinn and they can harm you back. In the XIV th c. Taqi ud-Dīn Abu-I-'Abbas Ahmad ibn 'Abd al-Halim 'Abd as-Salam ibn Taymiyyah, said: "The jinn may appear in human and animal form, so they may appear as snakes and scorpions etc., or in the form of camels, cattle, sheep, horses, mules and donkeys, or in the form of birds, or in the form of humans, as the Shaytaan came to Quraysh in the form of Suraaqah ibn Maalik ibn Ju'sham when they wanted to set out for Badr"145. In a modern publication on the jinn and human sickness by Dr. Abu'l-Mundhir Khaleel ibn Ibraheem Ameen in 2005 one reads: "Jinn also can appear as snakes, scorpions, cattle, donkeys, birds, and other animals. When the Prophet, upon him be peace and blessings, took the oath of allegiance from them in the valley of Batn al-Nakhla, he wanted them to appear to his community either in their own form or in other agreeable forms, not in the forms of such harmful animals as dogs and scorpions" ${ }^{146}$.

\section{Some Written Record of the Jinn in the XIII ${ }^{\text {th }}$ c. in Rūm Seljuk Territory}

That the jinn were recognised and recorded as present in the XIII ${ }^{\text {th }}$ c. in Rūm Seljuk territory, as elsewhere, is evidenced not only by the repeated depiction on a variety of surfaces of the Seal of Sulaymān, indicating control over the Jinn; but also in numerous texts, in both official and other written historical sources. The deed of endowment of Celal ad-Din Karatay for the Karatay Medrese, Konya, of July $23^{\text {rd }}, 1253$ is explict on this matter. It reads:

"I bear witness that there is no god but Allah, and that prophet Muhammed is His servant and messenger. Many praises and regards be to the prophet Muhammed (peace be upon him), and his companions as long as trees bloom their flowers and gardens yield crops. May the honorable caliph of Abbasis, Musta'sim Billah's holy rank be blessed.

May Allah exalt the word of Ebu'l Feth Keykâvus, the son of Sultan Glyaseddîn Keyhüsrev and the grandson of Alâaddin Keykûbat; master of all honorable sultans, the sultan of Allah's earth, the guardian of cities, protector of earthly wealth, the shining star of the caliphate heavens, a fountain of justice and compassion, a safe haven for jinns and humans, Allah's servant in the east and the west, the protector of Islam and muslims, the crown of the Seljuk dynasty, sultan of the land and both seas, the commander of the faithful; may Allah eternalize his sovereignty, may his orders be obeyed over the horizons" ${ }^{147}$.

In the context of this reference made to the Jinn in this document, it is noteworthy that the tile-work revetments within the Karatay Medrese itself carry examples of the six-pointed Seal of Sulaymān device $e^{148}$.

he lost his kingdom for a while) but".

144 Lane 1865, 29-30. See Lane 1865, 29-33, Note on the Jinn. As also s.v. 'Genii', Hughes-Hughes 1885, 135, citing from Lane 1865.

145 Majmoo' al-Fataawa, 19/44.

146 Abu Almundhir 2005, 45.

147 Karatay Medrese Konya Vakifname, translation at http://karatay.edu.tr/intl-students/endowment.html

148 Öney 1992, Resim 62. For further on the matter of the designs employed, Duggan 2016. 
Ibn 'Arabi at the start of the XIII ${ }^{\text {th }} \mathrm{c}$. in his work, which was taught by Sadr al-Dīn Qūnāwī in Konya, entitled: Ittihād al-kawnī... - The Universal Tree and the Four Birds, is a work dedicated to: "...Sultan of men and Jinn, Jānn son of jinn, pupil of man's eye, beneficent giver, Abū-alFawāris Sakhr b. Sinan, master of the reigns of generosity and eloquence", that is to Khâlid ibn Sinān b. 'Ayth al-'Absī, the Prophet of the barzakh ${ }^{149}$. Ibn 'Arabi also recounts from an authoritative source, an experience related by a woodcutter who met the Shaykh of the Jinn, one of the last survivors of the Jinn of Nișīin who had heard the Prophet of Islam preach ${ }^{150}$. Acknowledged proximity to, and reference to, the work of the jinn was a commonplace of the time, Yāqūt ibn-'Abdullah al-Rūmī al-Hamawī (1179-1229) records in respect to Tadmor/ Palmyra that, "Whenever people see a wondrous building whose builder is unknown to them, they attribute it to Solomon and the Jinn,..." ${ }^{\prime 151}$ the same had been expressed more than a century earlier by the crown prince Ibn al-Mu'tazz in his poem in praise of the Abbassid alMu'tadid and his palace "al-Turayyā", "Because nothing ever built by man can compare, no, nor anything built by the jinns of yesteryear"152. While 'Izz al-Din ibn Shaddād (1217-1285) noted there were sculptures of two copper jinns in the tower of the Water Gate at Ayyubid Harran, and that they served as talismans against snakes ${ }^{153}$, presumably meaning both snakes in a literal sense, and, perhaps more importantly, Jinn having the form of snakes; as is likewise represented on the Citadel at Aleppo, the carving in relief of two interlacing snake bodies with dragon heads above the arch of the main portal or Serpent Gate (Bāb al-Hayyāt) indicating it was under the protection of the jinn; while another example of the type, the representation on a gate, a place of transition, of Jinn in the form of dragons-snakes, it can be suggested, was on the Bagdad gate of 1221, Fig. 9, depicted with the tongues of the unbelieving jinn heldcontrolled by the Just Ruler of the Age.

It is related that Jelal ad-Dīn Rumi at the age of five in Balkh, "often jumped up from his place and became so agitated that the disiples of Bahā-e Valad would hold onto his waist. This was because spirit images and figures from the unseen World took on appearance before his sight, that is, envoys from among the angels, pious Jinn and humans of special distinction who are concealed by God's Domes"154. While in Konya, Kerrā Khātūn, Rumī's second wife relates "In our house there was a lampstand which had been built as tall as a person. It happened that from the beginning of the evening until the advent of dawn Mowlāna would remain standing and read the Ma'âref of Bahā-e Valad. One night a group of Jinn who inhabited our premises complained to me, saying: "We cannot support the brightness of the lamp, and the light of the lamp causes us great disturbance. Watch out that some harm does not come from us to the people of the house!"

Kerrā Khātūn said: "I told Mowlānā about this complaint. He smiled and for three days did not give any form of reply. After that he said: "After today do not worry. The Jinn have become my disciples and believe me. They will not cause harm to any of our offspring and friends"155.

Mowlānā Celal ad-Dīn Rumī said, "The repose of all mankind and the Jinn, and many benefits

149 Jaffray 2013, 63-77.

150 D. Gril, Hadith in the work of Ibn 'Arabī: The Uninterrupted Chain of Prophecy, Ibn 'Arabi Society, Vol. 50, 2011 at: http://www.ibnarabisociety.org/articles/ibn-arabi-and-hadith.html

151 Naaman 2016 fn. 14, citing Mu'jam al-buldān II, 17-19.

152 Smoor 1991, 100.

153 Jairazbhoy 1996, 22.

154 Aflaki 2002, 55, and in reference to God's Domes, of the occluded from normal sight, 707, fn. 48.

155 Aflaki 2002, 68. 
are to be found in incense ${ }^{1156}$, and he is reported to have said:

"Mowlāna Shams al-Din had the miraculous capacity of Moses to subdue the carnal souls (nafas) of the Jinn and human beings, as well as regarding the secret of the holy names and the secrets of things ${ }^{\prime \prime 157}$. And, in a state of ecstasy he said:

"And when you've learned the origin of man and the Jinn,

If the origin is one, what then this shyness of animals?

And if you saw a Jinni who has no face and back,

Why if you imagined lovers did it have a face and back?"158.

While a contemporary of Mowlānā Celal ad-Dīn Rumī, Mowlānā Shams al-Dīn-e Mardīnī was described as "the Mofti of the Jinn"159. The related title, mufti al-sakalayn (mufti of the people and the jinn), was subsequently given in Ottoman times to Shams al-Dīn Ahmed (1469-1534), known as Ibn Kamāl - Kamāl Pashazade ${ }^{160}$ and then to Ebû's-Su'ud Efendi in the reign of Süleyman Kanuní ${ }^{161}$.

Control over the Jinn was an aspect of many of those who were understood to have provided models of the Just Ruler in the Islamic world and it is noteworthy that both the Prophets Sulaymān and Dhū al-Qarnayn mentioned in the Qur'ān were related, together with İskandar-Alexander in the Islamic world, not just as the model of the Just Ruler, like Khusrev ${ }^{162}$ and Jamshid, but also linked through their recorded association with the Jinn, with having the Jinn at their command. Al-Biruni notes that a tradition recorded that Dhu'l-Qarnayn was a son of Bilqīs-Belkız ${ }^{163}$, the Prophet Sulaymān's queen, who was thought by some to have hairy legs indicating that she was the daughter of a jinnee ${ }^{164}$, implying that Dhu'l-Qarnayn was part Jinn. It was related by Dinnawari and Tabarī, that Persopolis was constructed by the Jinn working for the Prophet Sulaymān-Solomon, or by the dives for Jamshīd ${ }^{165}$ while Ibn Munabbih in the VIII ${ }^{\text {th }} \mathrm{C}$. and Mas'udi in the $X^{\text {th }}$ c. attributed the ruins of Persopolis to the Jinn working for the Prophet Sulaymān ${ }^{166}$ hence likewise, the "The Mosque of Solomon's Mother" as also the "Throne of Sulaymān" in the Murghab plain, as the "Throne of Jamshīd" at Persopolis, while Baalbek, was said to have been built by the jinn, like Tadmor/Palmyra, by order of the Prophet Sulaymān ${ }^{167}$.

Examples of Representations of the Members of the Armies of the Jinn on Rūm Seljuk XIII ${ }^{\text {th }} \mathrm{c}$. 8 Pointed Sun-Star Tiles

Ibn Bibi writes of these Seljuk palace-pavillion tile revetments: "The "kafesli" (lattice pattern) adorned walls should be so colourful, the colours of the birds in the sky should fade with envy, all

156 Aflaki 2002, 173.

157 Aflaki 2002, 430.

158 Aflaki 2002, 288.

159 Aflaki 2002, 105.

160 Kalın-Ayduz-Dagli 2014, 335.

161 TDV iA, s. v. "Ebû's-Su'ud", 25, 239.

162 The Just King, Kisrá Anúshirwán. "Al-Malik al-Adil" = the Just King. Kisra, Chosroë.

163 Ball 2012, 142.

164 Lafrate 2015, 198.

165 Mottahedeh 2013, 256. For the conflation of Jamshīd and Solomon, see for example, Bağcı 1995, 108; an association between the two already denounced in the VIII ${ }^{\text {th }}$ c. by Ibn al-Muqaffa (d. 759) as chronologically unsound, Browne 1997, 113.

166 Mousavi 2012, 84

167 Mottahedeh 2013, 249. Re Tadmor/Palmyra built by the jinn, see Yāqūt's Mu'jam al-buldān, II, 17-19. 
laid on with turquoise and blue, so blue, the watchman of the sky (Saturn ${ }^{168}$ ) should be driven into jealousy"169. And this characteristic Rūm Seljuk tile lattice pattern was designed to hold a repeat of shaped apertures filled with eight pointed suns-stars. It is of note in respect to this sun-star form that although somewhat later in date, Abd al-Karīm al-Jili (1365-1424) in his mystical astrology contained in his al-Insānu'l-kāmil fi ma'rifati'l-awākhir wa'l-awā'il, in respect to the Heaven of the Sun, the fourth of the Seven Heavens, relates that, "It is created from the light of the heart (qalb). The Sun in his heaven is like the heart in man - a mirror of Deity: while the heart displays the sublime degrees of existence connoted by the Name Allah, the Sun is the source and principle of the elemental world. Idris, Jesus, Solomon, David, and most of the prophets dwell in the heaven of the Sun; its ruling angel is Isrāfil” ${ }^{170}$; Abd al-Karīm al-Jīi making the association between the shape of the sun and the light of the Almighty and with the light in the mirror of the polished heart, with the dwelling place of the Prophet Sulaymān in the Heaven of the Sun and, in consequence, the 8 pointed sun-star shape, forming a type of the Khatam Sulaymān-Seal of Sulaymān ${ }^{171}$, would seem to be a most appropriate form on which to depict the armies of the Prophet Sulaymān.

It is suggested that it is the case that the largest surviving collection of depictions of the Jinn from the pre-Mongol period in the Islamic world are those that are depicted on these tilework revetments in Rūm Seljuk territory. The identification of these figures as depictions of members of the army of jinn, quite different in type from later Mongol-Ilkhanid or Ottoman depictions of the jinn, has considerable implications - not least concerning matters of the identification of similar depictions of these figures elsewhere and in other materials. It is to be noted that the later, 1280 dated copy of Abū Yahya Zakarīyā ibn Muhammad ibn Mahmud al-Qazvīnī's Kitab-i 'Ajā'ib al-makhlūqāt wa'l-gharā'ib al-Mawjudat-Marvels of Creatures and Miracles of Things Existing, ${ }^{172}$ written in the author's lifetime, 1203-1283, shows that the section in this work concerning the jinn, recording for example the 420 types of Jinn brought before the Prophet Sulaymān, was a subsequent insertion by another hand into al-Qazvīnī's text ${ }^{173}$.

\section{Depictions of Some of the Variety of Types of Jinn Figures Depicted on the 8 Pointed Tiles} from Kubadabad
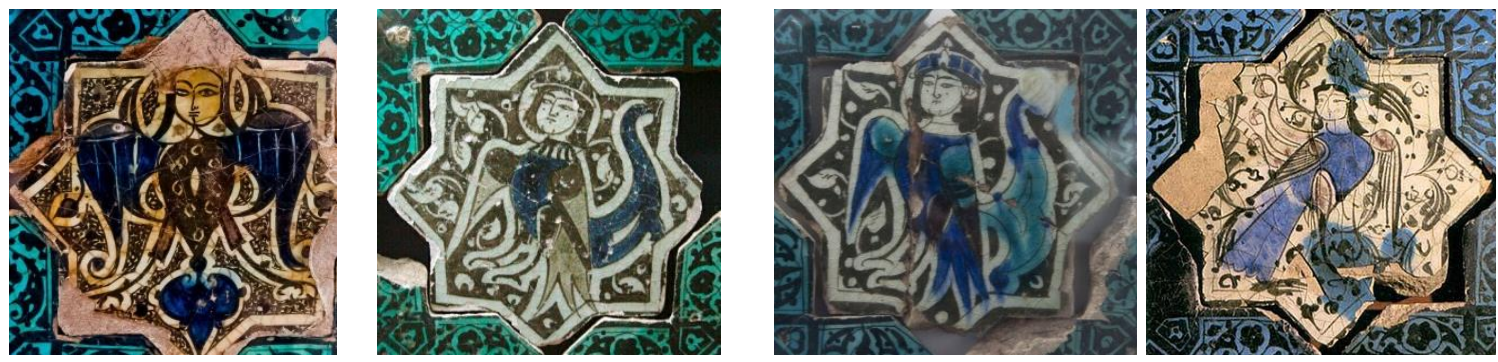

168 The planet Saturn, "The watchman of the sky" as was employed by Shaikh Nizami of Ganja in his Sikandernama, Canto V.:

"From his waist the watchman of the sky (Saturn) suspended "A golden bell, for the guarding of the King" Nizami 1881, 44.

169 Ibn Bibi 1996, Vol. I, 363.

170 Nicholson 1980, 123.

171 Jan-Shaker 2007, 14.

172 Munich cod. arab. 464.

173 Berlekamp 2005, 653. 

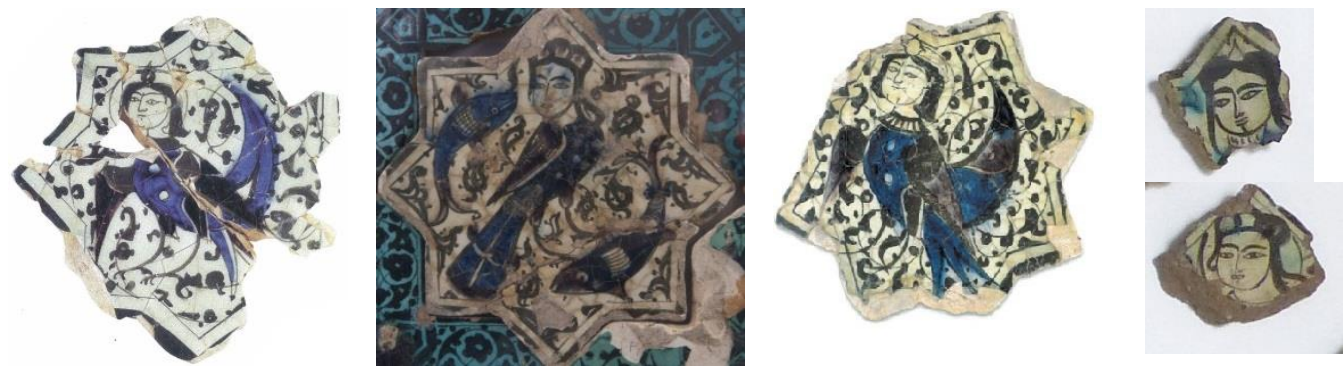

Fig. 1. A group of representations of the Jinn of the Air - a crowned human-headed bird and probable fragments thereof.
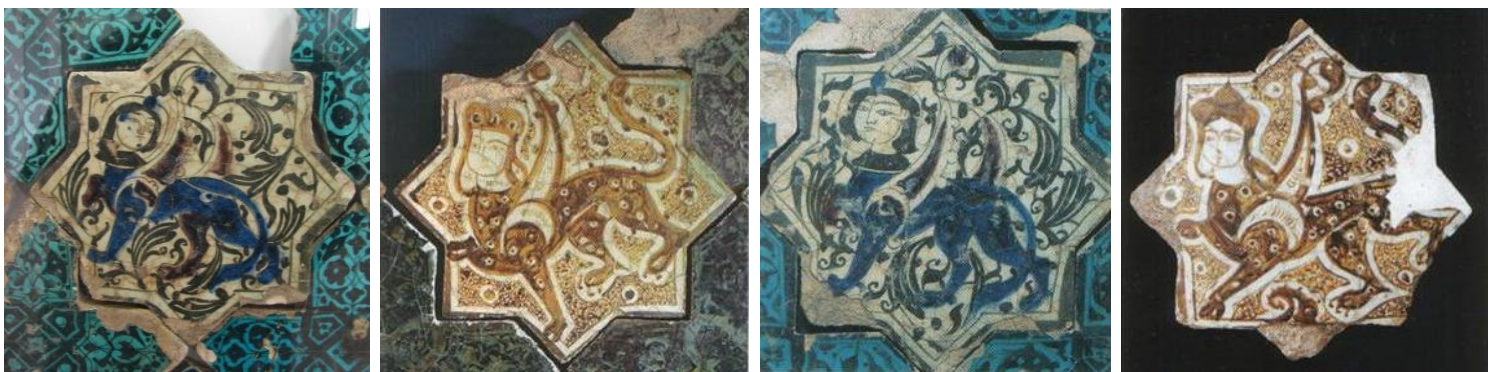

Fig. 2. A group of representations of the Jinn of the Land - a crowned human-headed winged feline.

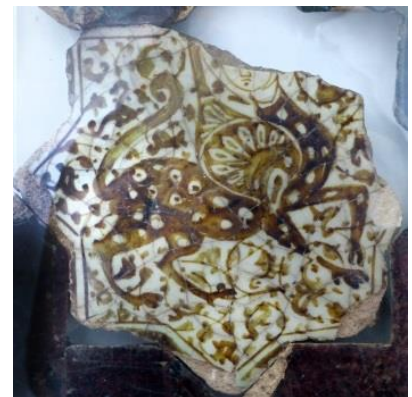

Fig. 3. The representation of another type of Jinn of the Land - a human headed winged cloven hoofed creature.
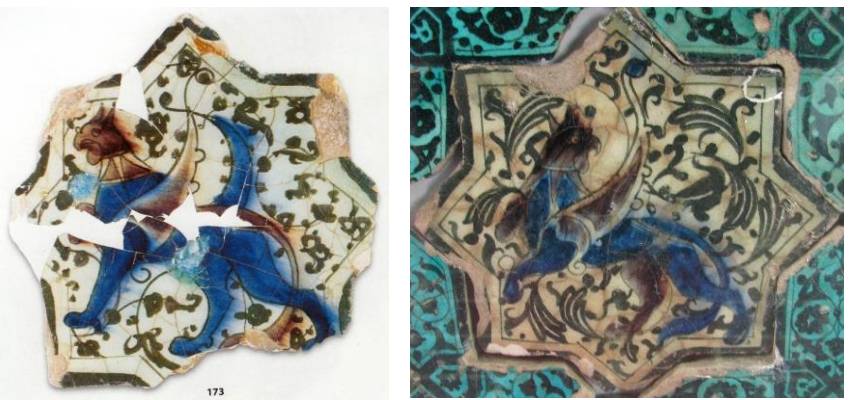

Fig. 4. The representations of a griffon-like Jinn of the Land a feline body with wings and a bird's head with ears.

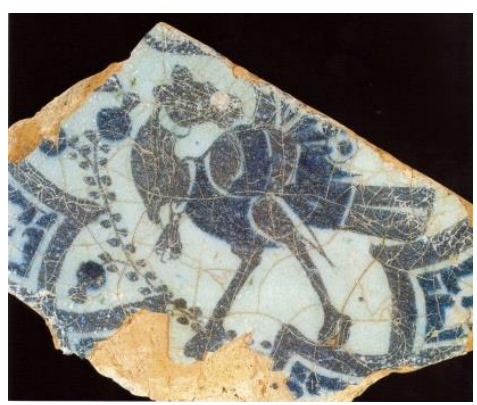

Fig. 5. The representation of a Jinn of the Land, or of the steed of the Jinn, - a camel-ostrich.

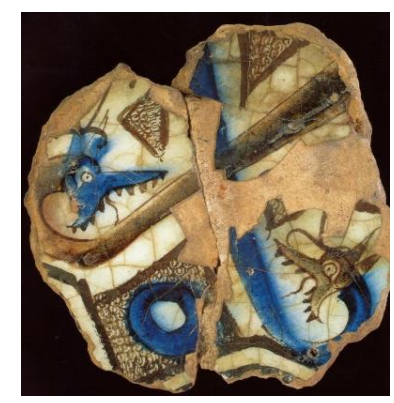

Fig. 6. The representation of two Jinn - as dragon-headed serpentsnakes.

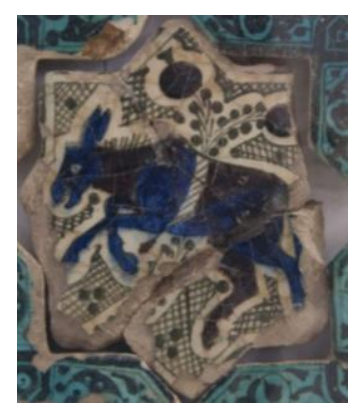

Fig. 7. The representation of a donkey/mule, one of the forms taken by the Jinn, as noted by ibn Taymiyyah. 

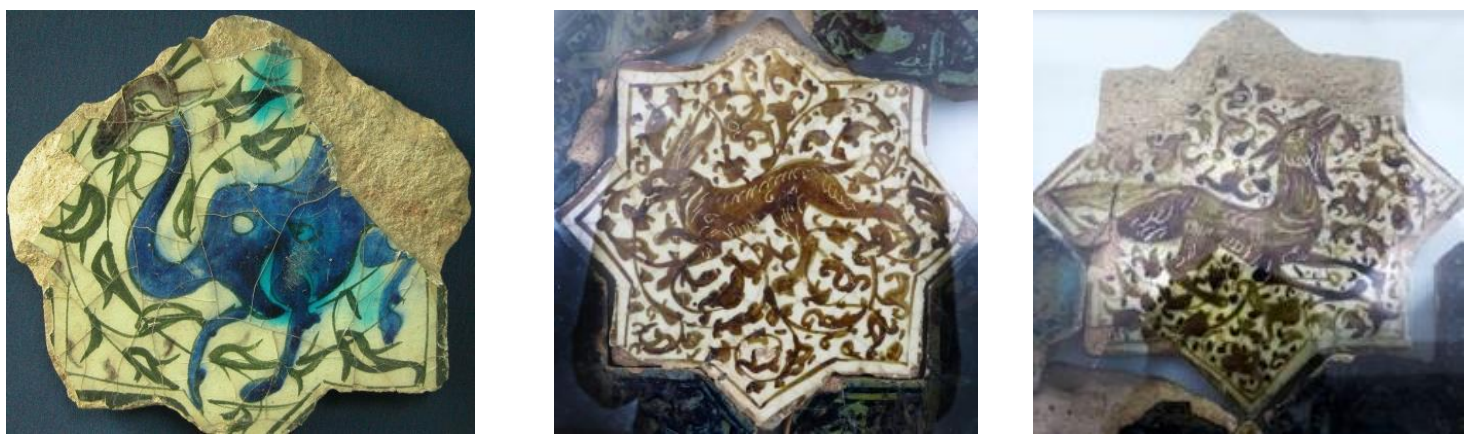

Fig. 8. Possible representations of Jinn in animal form.

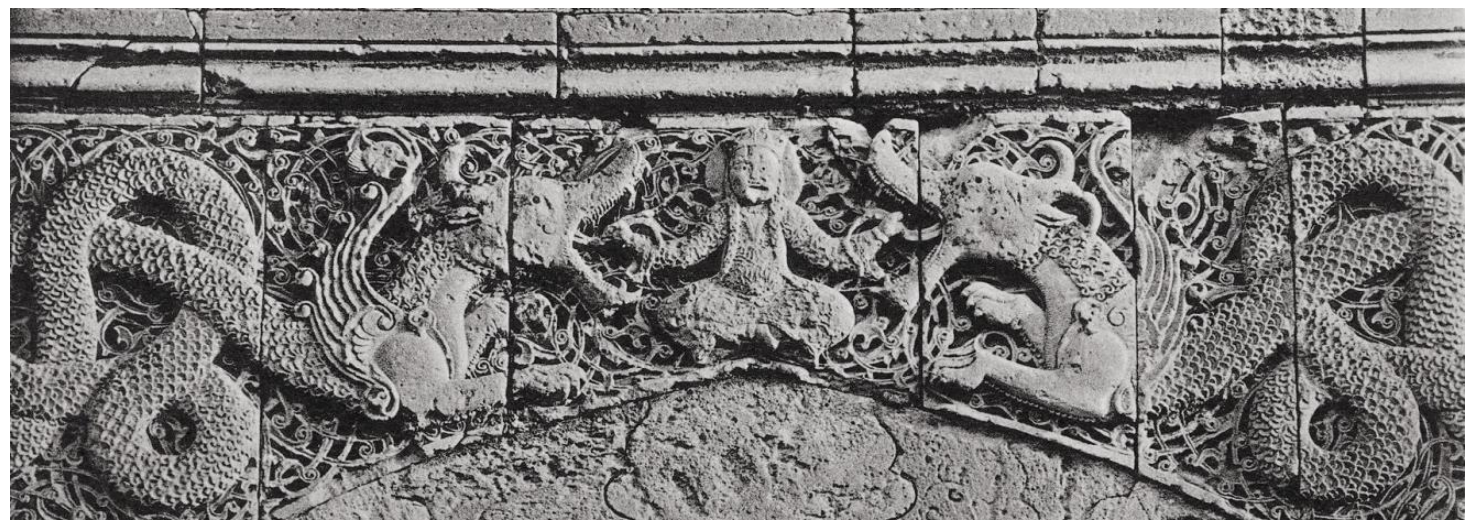

Fig. 9. The relief on the so-called Bab al-Talism-Talisman Gate of Bagdad of A.H. 618-1221 A.D., blown up in 1917. Photograph from, Sarre-Herzfeld 1911, III, Taf. XI. Depicting it is suggested the Just Ruler exercising control over the Jinn.

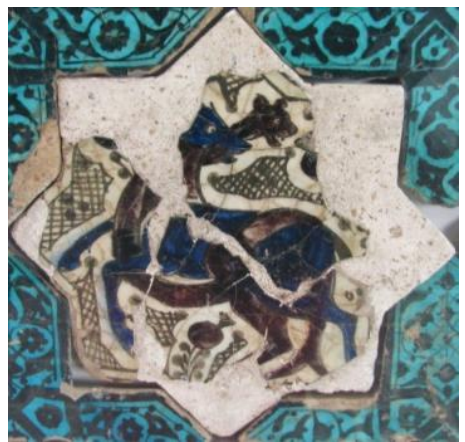

Fig. 10. A damaged 8-pointed underglaze tile with the depiction of a bovine quadruped but with apparently two heads, one belonging to the jinn riding it.
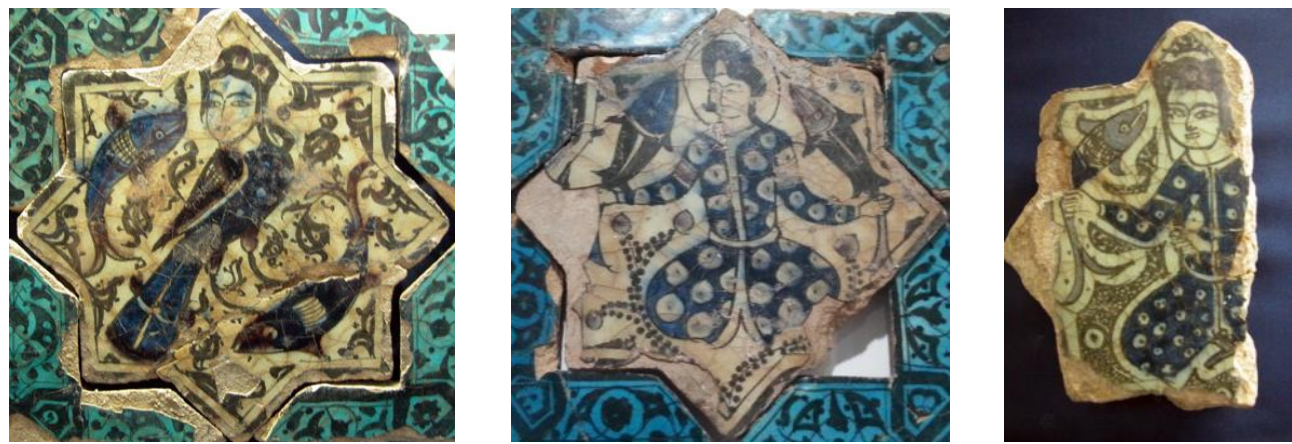

Fig. 11. On separate tiles that possibly can be read as related depictions narrating key moments in the Story of the Devil (Jinn) Who Took Solomon's Signet Ring. (a) of the Devil (Jinn - Sakhr/Jasadan) who dropped Sulaymān's ring in the sea which was swallowed by a fish, (b) of Sulaymān with the two fish he was paid for his labour, and (c) of Sulaymān holding in his right hand the fish that had swallowed his ring. 
In respect to interpreting Fig. 3 above, Amira El-Zein has states that deer were looked upon as a magical animal, that people often alleged that "deer are the cattle of the jinn", ${ }^{174}$ and so perhaps the composite winged quadruped with a human head and cloven hooves depicted in Fig. 3, can also be understood to represent a variety of Jinn of the Land, like the Jinn depicted in Fig. 1, of the Air, and, Fig. 2, the Jinn of the Land ${ }^{175}$.

Although R. Arık and O. Arık write concerning Fig. 5: "This is a depiction that does not fit in any thematic and symbolic group, and which has nothing to do with tradition and belief: a picture of an ostrich. It has the body of a bird and the head and legs of a camel. The feathers of its wings are decorated in the usual colors and pictorial qualities and a small bell hangs on its camel neck. It is moving forward with its head turned back. This caricature like painting is a typical example of concept painting, which is often mentioned in the studies of miniature art. What is pictured here is not the concrete description of a real being. Instead, by bringing together the forms of a camel and an ostrich, an illustrated description is presented of a compound and new abstract concept ${ }^{176}$, a "camel-bird"177. However, more recently Robert Irwin has stated that the old Arabian belief was that camels were themselves descended from the jinn, that the camel was frequently compared to the ostrich, and that the ostrich was itself classified as a kind of camel by the early Arabs ${ }^{178}$; while in the $X^{\text {th }} \mathrm{c}$. in the Rasā'il Ikhwān al-Safā in The case of the animals versus man before the King of the Jinn, in the case of the pig: "Another (jinni) said, "He is a cross between cattle and beasts, like the giraffe who is a cross between cow, leopard, and camel, or like the ostrich, whose form resembles not only that of a bird but also that of a camel"179. While in XI ${ }^{\text {th }}$ C. Syria, Abū l-'Alā al-Ma'arrī (d. 449 H/1057 A.D.) in his Risālat al-ghufrān, The Epistle of Forgiveness, writes that a Jinn relates:

"I frightened Blacks, by visiting their womenfolk, and Byzantines, and Turks, and Slavs, and Afghan Ghur!

I'd ride an ostrich in the dark, haphazardly

Or not; then a wild bull, who spent the night in freezing cold...

174 El-Zein 2009, 92.

175 For further on the terminology and the problems with the orientalist terminology derived from antiquity, based upon a resemblance of form, rather than one of meaning, in respect to the Jinn of the Land and the Jinn of the Air, the so-called "sphinx" and "siren"-"harpy", see Duggan 2015. The continuing use of this orientalist terminology, as in 2016, in the catalogue of the Metropolitan Museum of Art's exhibition entitled, Court and Cosmos: The Great Age of the Seljuqs, Yale University Press, New Haven and London, seems unhelpful for our comprehension of the meaning conveyed by the representation of these figures in Seljuk and Islamic art. The depiction of these figures, the jinn of the land being described as, "the sphinx was the solar symbol par excellence" sic., idem. 243; "the sphinx, a fantastic creature revered since ancient times for its protective powers and solar/astral connotations" sic., idem. 248; and the jinn of the air being described as a harpy, "The image of the half-woman, half-bird monster, whose sources belong in the ancient past, is here used in apotropaic mode" sic., idem. 245. It seems evident that the mistaken use of the orientalist terminology derived from antiquity to identify these depictions as such, has unfortunately resulted in the inability in the past to identify the subject matter of this Seljuk palace tile-work as being related to Sulaymān and "The Second Sulaymān," even though it was known that this was a title employed by numerous rulers, examples of which are noted above.

176 Rather than being a "new abstract concept," the Struthiocamelus, the camel-bird, the ostrich, was well known in antiquity, Aristotle had described it as in part bird and in part quadruped; and Pliny was disposed to class the ostrich with the beasts rather than birds, Plin. NH 10. I. The Ostrich. "The history of the birds follows next, the very largest of which, and indeed almost approaching to the nature of quadrupeds, is the (ostrich) Struthiocamelus (from the Greek, signifying a "little sparrow," and "a camel") of Africa or Aethiopia".

177 Arık-Arık 2008, 314.

178 Irwin 2010, 68-69.

179 Ikhwān al-Safā' 1978, 63; reprinted, Nasr-Aminrazavi 2008, 271. 
A trackless desert where the demons hum,

A wasteland, only by the bravest jinn inhabited,

White, mighty, heavy, like white clouds,

yet noble, speaking with a whispering.

At night horses with wings would carry us,

unlike the horses of mankind,

And female camels, faster than your eyes could see, created from a cross of ostrich and of camel,

Which in one night would pace from 'Alwah

to the hamlets of Tashkent, with only muffled sounds.

There was no piety among us in those days:

Religion suffered a relapse and we were not astute ${ }^{\prime 180}$.

Ostriches, like camels and camel-ostrich crosses, were described as mounts for the jinn ${ }^{181}$, "According to one legend, the jinn were believed to be the first inhabitants of the earth. ... The jinn often rode animals, such as the ostrich, gazelle, camel, sheep, and dog; consequently, the Arabs did not hunt the riding animals of the jinn after dark. For the spirits usually showed themselves at night and, although normally not seen, they could be heard and touched" ${ }^{\prime 182}$. It therefore seems reasonable, in this context of the representation of the armies of the Second Sulaymān, the Just Ruler, to suggest that Fig. 5, the depiction of a camel-ostrich or camel-bird, was understood th that time to represent either a jinn or the steed of a Jinn.

Jann, the plural form of jinn can mean: father of the jinn, a small white serpent, a great serpent, or a harmless house snake and, as such, Jann is mentioned in connection with the Prophet Musa-Moses staff ${ }^{183}$; and the depictions of snakes-serpents-dragons in Seljuk art, e.g. Fig. 6, can be understood to represent Jinn in the form of a snake-dragon, as is noted above.

Extraordinarily for a depiction on the walls of a palace, there is the represention of a donkey or mule, Fig. 7. It is perhaps only within this context, of representing one of the members of the armies of Sulaymān, of one of the forms taken by the Jinn, as noted by ibn Taymiyyah, that this depiction has sense. Further, it may be a depiction of what is recorded in the hadith cited above, "Recite Ayat al-Kursi (Surah Al-Baqara, Verse 255), for no one (who) recites it when he enters his house, except that Shaytan (the Jinn) leaves, passing wind like a donkey".

It may also be the case that some of the other creatures on these tiles, that do not have wings and human heads on the bodies of animals and birds, nor have serpent or dragon forms, such as the examples given in Fig. 8 above, may also have been understood to represent Jinn in animal form, as, "In addition to dogs, deer, and ostriches, jinn are described as embodying the forms of many other animals such as foxes and porcupines, as well as the raven, the dove, the hedgehog, and the rabbit ${ }^{\prime 184}$, not least the fragment showing a dog-like creature walkingrunning over a leaping fish ${ }^{185}$. While Fig. 10 can be understood to depict both a jinn and a bovine creature, its head beside the head of the jinn.

Sulaymān may also be indicated through the tiles that depict a jinn of the air figure with a

\footnotetext{
180 Van Gelder-Scholer 2016, 126.

181 El-Zein 2009, 92.

182 Dols-Immisch 1992, 215.

183 Qur'an An-Naml, 27:10; 28:31.

184 El-Zein 2009, 93.

185 Arık-Arık 2008, 309, fig. 287.
} 
fish on either side, the depiction of a seated figure with a fish held in each hand ${ }^{186}$, and a third depiction, of a figure in the same dress with a single fish held in the right hand (Fig. 11). These three depictions from Kubadabad (together with a part of another from the inner castle at Alanya $^{187}$, and a fragment bearing a fish from the Belkiz-Aspendos Palace or Antalya ${ }^{188}$, indicating these designs formed part of the $\mathrm{XII{ } ^ { \text { th } }}$ c. Seljuk palace tile design repertory), may be related to the account recorded in Tabari, of Solomon's Campaign against the Father of His Wife, Jaradah, and the Story of the Devil Who Took Solomon's Signet Ring, concerning the loss of Sulaymān's seal ring ${ }^{189}$, which was dropped into the sea by a devil-jinn ${ }^{190}$, al-Thalabi names it the demon, Sakhr ${ }^{191}$, who had occupied Sulaymān's throne for 40 days - indicating a long time, and is recorded as the name of the jinn who constructed Sulaymān's throne ${ }^{192}$ or possibly Jasadan. The throne-less Sulaymān's wage for a day of labour with a fisherman was two fish, one of which he sold for bread, the other he cut open to grill, and one evening inside it he found his own ring, repentance and renewed proximity to his Lord ${ }^{193}$. These scattered images "read" together, possibly formed a cautionary reminder to the sultan about his household, and formed what may have been read as a minor narrative.

\section{Conclusions}

It seems to be evident from the sources cited in the first part of this article that these $\mathrm{XIII}^{\mathrm{th}} \mathrm{c}$. Rüm Seljuk eight-pointed sun-star tiles display the varied members of the four armies of the Prophet Sulaymān as described in the written sources, of people, jinn, beasts and birds, as seems also to have been the case with the mina'i depictions on at least some of the surviving earlier tilework from the Kılıç Arslan II köşkü-pavillion in Konya. It can therefore be understood that these varied depictions served to indicate that the ruling Rūm Seljuk Sultan was to be understood, through the representation of these four types of figures, as being The Second Sulaymān, the Sulaymān of the Time, as was stated in contemporary literary sources, that describe Seljuk Sultans from the reign of Kılıç Arslan II onwards as such.

The representations of the Jinn on this tile-work present us today with the largest surviving collection of depictions of the various forms of the Jinn recorded in the Islamic world prior to

186 From the Great Palace at Kubadabad, Arık 2000, p. 136, fig. 185. It has been related to Al-Hūt, Aquarius- Pisces.

187 A further tile fragment with a figure and fish of this type, from the inner castle at Alanya, Arık-Arık 2008, 274; Arık-Arık 2008, fig 223.

188 From Bilqīs-Aspendos or Antalya, Arık-Arık 2008, fig. 213.

189 Likewise, it is related the loss of another signet ring, that of the Prophet's which slipped from the finger of the Caliph 'Uthman, and which was lost in the Arees well at Medina, is said to have marked after six years of "just" rule, the start of six years of "unjust" rule that culminated in the deposition and eventual murder of this Caliph, the third of the four "rightly guided" caliphs.

190 In respect to the jinn described as devil as noted above, see, Qur'an Sad 38:37-38, "And [also] the devils [of jinn] every builder and diver. And others bound together in shackles".

191 Brinner 2002, 539.

192 Brinner 2002, 512

193 Tabarī, Ibn Humayd related to us - Salamah - Ibn Ishaq - a scholar - Wahb b. Munabbih: "When forty days had passed, the Devil flew away from his (Sulaymān's) council chamber. As he passed over the sea, he threw the signet ring into it, and a fish swallowed it. One of the fishermen saw that fish and caught it. Solomon had worked for him from the beginning of that day until evening, so he gave Solomon his two fish, [including] the one that had taken the signet ring. Solomon went out with his two fish and sold the one in whose stomach there was no signet ring for some loaves of bread. He then applied himself to the other fish, cutting it open in order to grill it, and was confronted by his signet ring in its stomach. He took it, placed it on his hand, and fell down, prostrating himself to God. The birds and jinns surrounded him, and people approached him, and he knew that what had come upon him was only because of what he had let happen in his household. He returned to his dominion and manifested repentance for his sin" Tabari 1985, III, 171; Brinner 2002, 542. 
the Mongol invasions and, in consequence, these varied depictions of the Jinn provide us with important evidence concerning the associations and meaning that was understood at that time to have been indicated, through the representation of these same types of figures elsewhere, over a range of materials, from stone sculptures and carvings to works in bronze and textiles to wood carving and ceramics, produced within this cultural-religious context from the $X^{\text {th }}$ to the XIIIt ${ }^{\text {th }}$ centuries. To see the seated human ruler figure (presumably representing the Abbāsid Caliph Nāșir li-Dīn Allāh as The Just Ruler), holding the tongues of the Unbelieving Jinn (serpentdragons) one in in each hand over the "Talisman" gate to Bagdad of 1221 (Fig. 9), to see the relief sculpture of a human headed bird on a city wall or a han, to see a relief carving of a human headed winged lion on a bastion or city wall, to see a depiction of the camel-bird or of a donkey/mule on a palace tile, or the Seal of Solomon device in its eight or six pointed forms, was to be reminded that one was inhabiting a world of the jinn, as well as of people, beasts and birds, in the realm of the Second Sulaymān, of the Sulaymān of the Time, the Just Ruler of the Time.

In consequence, it can be understood that the four types of figures in these designs within the tile-work lattice, figures of a kind employed elsewhere in Seljuk art, as with the same types of figures employed elsewhere within this Islamic cultural-religious environment, were employed to express and remind, not only in written text, but in design, in visual terms of the legitimacy of the ruler, with the Just Ruler being the Sulaymān, the İskandar/Alexander, the Dhü'l Qarnayn, the Keyhusrev, the Jamshid, of the Time/Age. That is, that the structure, be it a palace or a pavilion, or an object, was dressed, in both text-inscription, and design, in the manner of the kiswa over the Ka'ba, or a garment with both design and tiraz, and, in this instance, that the figural designs employed on these 8 pointed tiles within the lattice of these tile-work revetments, signified and served to remind, in the visual language of design, that the Seljuk Sultan was, "The Second Sulaymān," meaning the Just Ruler of the Age. 


\section{BIBLIOGRAPHY}

Aflaki 2002

Abu Almundhir 2005

Aigle 2009

Öney 1980

Anas 2013

Arabi 1978

Arabi 1991

Arık 2000

Arık-Arık 2008

Anooshahr 2009

Attar 1984

Auer 2012

Auld 2005

Bağcı 1995

Bağcı 2005

Baker 2004

Ball 2012

Berlekamp 2005

Bibi 1996

Blair 1992

Blair - Bloom 1995

Brinner 2002

Bosworth 1977

Bosworth 2010
Shams al-Dīn Ahmad Aflākī, The Feats of the Knowers of God: Manāqeb Al'ärefin. Trans. J. O'Kane, Brill, Leiden, 2002.

Abu Almundhir K. ibn I. Ameen, The Jinn and Human Sickness: Remedies in the Light of the Qur'aan and Sunnah. Trans. N. Al-Khattab, Darussalam, Riyad, Jeddah, Sharjah, Lahore, London, Houston, New York, 2005

D. Aigle, "Legitimizing A Low-Born, Regicide Monarch: The Case Of The Mamluk Sultan Baybars And The Ilkhans In The Thirteenth Century". (2009) 1-18, at: https://hal.inria.fr/docs/00/38/33/36/PDF/Baybars.pdf

G. Öney, "Anatolian Turkish Minor and Decoration". In, Ekrem Akurgal, Léo Hilber (photography), The Art and Architecture of Turkey, Rizzoli 1980.

Al-Muwatta of Iman Malik Ibn Anas. Routledge, London 2013.

The Tarjum-an al-Ashw-aq, A collection of Mystical Odes by Muhyi'dd-in ibn al'Arabi. Trans. R. A. Nicolson, Preface Dr. N. Lings, Theosophical Publishing House, Ltd., London 1978.

Ismail Hakkı Bursevi's translation and commentary on Fusus al-Hikam by Muhyıddın ıbn 'Arabı. Rendered into English by Bulent Rauf with the help of R. Brass and H. Tollemache, III., Muhyıddın ıbn 'Arabı Society, Oxford, İstanbul, San Franciso 1991.

R. Arık, Kubad Abad, İş Bankasi Yay. İstanbul 2000.

R. Arık - O. Arık, Tiles: Treasures of Anatolian Soil, Tiles of the Seljuk and Beylik Periods. Kale Group Cultural Publications İstanbul, 2008.

A. Anooshahr, The Ghazi Sultans and the Frontiers of Islam. A Comparative study of the late medieval and early modern periods. Routledge, London and New York 2009.

Farid ud-Din Attar, The Conference of the Birds. Trans. Trans. A. Darbandi - D. Davis, Penguin, London 1984.

B. H. Auer, Symbols of Authority in Medieval Islam: History, Religion and Muslim Legitimacy in the Delhi Sultanate. I. B. Tauris, London 2012.

S. Auld, "The Minbar of Al-Aqsa: Form and Function". Ed. R. Hillenbrand, Image and Meaning in Islamic Art, Altajir Trust, London, (2005) 42-60.

$\mathrm{S}$. Bağ $\mathrm{Cl}$, "A New Theme of the Shirazi Frontispiece Miniatures: The Divan of Solomon". Ed. G. Necipoğlu, Muqarnas XII, Brill (1995) 101-110.

S. Bağcl, "Catalogue entries Nos. 238, 239". In, Ed. David J. Roxburgh, Turks: A Journey of a Thousand Years, 600-1600. Royal Academy of Arts, London 2005.

P. Baker, Islam and the Religious Arts. Bloomsbury Academic, London 2004.

W. Ball, "Some Talk of Alexander Myth and Politics in the North-West Frontier of British India". Eds. R. Soneman, K. Erickson, I. R. Netton, The Alexander Romance in Persia and the East Barkhuis (2012) 127-160.

p. Berlekamp "Al-Qazvivi". Ed. J. W. Meri, Medieval Islamic Civilisation: An Encyclopedia, Vol. 1, A-K, Routledge, New York London (2005) 651-654.

Ibn Bibi El-Hüseyin b. Muhammed b. Ali El-Ca'feri Er-Rugadi, El Evamirü'l-Ala'iye Fi'l-Umuri'l-Ala'iye, (Selçukname)., Vols. I, II. Trans. M. Öztürk. Ankara 1996.

S. Blair, The Monumental Inscriptions from Early Islamic Iran and Transoxiana. Brill, Leiden 1992.

S. S. Blair - J. Bloom, Art and architecture of Islam 1250-1800. New Haven and London 1995.

Arā'is Al-Majālis Fi Qisas Al-Anbiyā', or "Lives Of The Prophets," as recounted by Abu Ishak Ahmad ibn Muhammad ibn Ibrahim al-Thalabi. Trans. W. M. Brinner, Brill, Leiden, Boston, Köln 2002.

C. E. Bosworth, The later Ghaznavids: Splendour and decay, the dynasty in Afghanistan and Northern India 1040-1186. New York 1977.

C. E. Bosworth, The History of the Seljuq State: A Translation with Commentary of the Akhbar al-dawla al-saljuqiyya. Routledge 2010. 
Browne 1997

Burton 2008

Cipa 2017

Darke 1978

Darling 2013

Dols-Immisch 1992

Duggan 2006

Duggan 2008

Duggan 2011

Duggan 2015

Duggan 2016

Duggan 2018

Eddé 1999

Van Ess 2016

Frank 1995

Frenkel 2014

Gaffney 1994

Van Gelder-Scholer 2016

Glassié-Smith 2003

Hillenbrand 1999
E. G. Browne, A Literary History of Persia. Vols. I-IV, II. Iranbooks, Bethseda, Maryland 1997.

Sir Richard Burton, Arabian Nights in 16 Volumes. Vol. IV, Cosimo Classics, New York 2008.

M. Erdem Cipa, The Making of Selim: Succession, Legitimacy, and Memory in the Early Modern Ottoman World. Indiana University Press, Indiana, 2017.

The Book of Government or Rules of Kings: The Siyar al-Muluk or Siyasat-nama of Nizam Al-Mulk. Trans. H. Darke, Routledge \& Kegan Paul, London, Henley and Boston 1978.

L. T. Darling, "Mirrors for Princes in Europe and the Middle East: A Case of Histiographical Incommensurability". Ed. A. Classen, East Meets West in the Middle Ages and Early Modern Times: Transcultural Experiences in the Premodern World. Walter de Gruyter (2013) 223-242.

M. W. Dols-D. E. Immisch, Majnun: The Madman in Medieval Islamic Society. Oxford University Press. Oxford 1992.

T. M. P. Duggan "The motifs employed on Rum Seljuk $13^{\text {th }}$ century eight pointed star tiles from Antalya Province and elsewhere in Anatolia: an interpretation". ADALYA IX (2006) 149-219.

T. M. P. Duggan, "The plaster and paintwork from Evdir and Kırkgöz Hans by Antalya - and some implications drawn from these finds and related material concerning the original appearance of these and other $13^{\text {th }}$ c. Seljuk State buildings". ADALYA XI (2008) 319-358

T. M. P. Duggan, "Some Localizations in Western Cilicia Relating to the 1225 Campaign of Sultan Alaed-Din Keykubat". In Anadolu ve Çevresinde ORTAÇAĞ 5 (2011) 221-238.

T. M. P. Duggan, “The O'Grady factor and false resemblance - blinding Orientalisms and misapprehensions of the $13^{\text {th }}$ century in the absence of due contextualisation and a little common sense". Ed. A. Arıkan, Akdeniz Üniversitesi, Edebiyat Fakültesi, İngiliz Dili ve Edebiyatı Bölümü, I. Dil, Talat S. Halman Kültür ve Edebiyat Çalıştayı, Haziran 2015, Talât Sait Halman'a Armağan Kitabı. (2015) 178-198.

T. M. P. Duggan, "Review of S. Redford, "Intercession and Succession, Enlightenment and Reflection: The Inscriptional Program of the Karatay Madrasa, Konya". Ed. A. Eastmond, Viewing Inscriptions in the Late Antique and Medieval World. Cambridge (2015) 148-169. Cambridge University Press, Hardback, 275 Pages (73 Illustrations) ISBN: 9781107092419 ", Libri II (2016) 1-62.

T. M. P. Duggan, "On Reading The Meanings Carried By The Zigzag Design In Islamic Art," XXI. Uluslararası Ortaçağ Türk Dönemi Kazıları ve Sanat Tarihi Araştırmaları Sempozyumu. Antalya, October 2017, proceedings forthcoming 2018.

A.-M. Eddé, La principauté Ayyoubide d'Alep: (579/1183-658/1260). Franz Steiner Verlag 1999.

J. Van Ess, Theology and Society in the Second and Third Century of the Hijra: A History of Religious Thought in Early Islam. Vol. 1, Brill, Leiden 2016.

A. G. Frank, Turkmen Reader. Dunwoody Press, Springfield, VA 1995.

Y. Frenkel, The Turkic Peoples in Medieval Arabic Writings. Routledge, London 2014.

P. D. Gaffney, The Prophet's Pulpit: Islamic Preaching in Contemporary Egypt. University of California Press, Berkley and Los Angeles, CA 1994.

'Ala al-Ma'arrī, The Epistle of Forgiveness or A Pardon to Enter the Garden, Trans. G. J. van Gelder-G. Scholer, New York University Press, New York \& London 2016.

C. Glassié-H. Smith, The New Encyclopedia of Islam. Rowman Altamira, Walnut Creek, CA 2003.

C. Hillenbrand, The Crusades: Islamic Perspectives. Edinburgh University Press, 
Edinburgh 1999.

Hoffman - Redford 2017 E. R. Hoffman - S. Redford, "Transculturation in the Eastern Mediterranean". Eds. F. B. Flood, G. Necipoglu, A Companion to Islamic Art and Architecture, John Wiley and Sons. Oxford (2017) 405-430.

Hughes-Hughes 1885 P. Hughes, T. P. Hughes, Dictionary of Islam: Being A Cyclopaedia Of The Doctrines, Rites, Ceremonies, And Customs. Together With The Technical And Theological Terms of The Muhammadan Religion, With Numerous Illustrations. W. H. Allen and Co., London 1885.

Ikhwān al-Safā' 1978 Ikhwān al-Safā' The case of the animals versus man before the King of the Jinn: a tenth-century ecological fable of the Pure Brethren of Basra. Trans. L. Goodman, Twayne, Boston, Vol. 1., 1978.

Irwin $2010 \quad$ R. Irwin, Camel. Reaktion Books. London 2010.

Jaffray 2013 Muhyiddīn Ibn 'Arabī, The Universal Tree and the Four Birds-Treatise on Unification (Ittihād al-kawnī). Trans. \& Commentary A. Jaffray, Anqa Publishing, Oxford, 2013.

Jairazbhoy 1996 R. A. Jairazbhoy, Art and the Cities of Islam. Ferozsons, Karachi 1996.

Jan-Shaker 2007

A. S. Jan \& S. A. Shaker, Symmetries of Islamic Geometrical Patterns. World Scientific Publishing, Singapore 2007.

Jayyusi $2012 \quad$ Classical Arab Stories: An Anthology. Ed. S. K. Jayyusi, Columbia University Press, New York 2012.

Kalin-Ayduz-Dagli 2014 i. Kalin-S. Ayduz-C. Dagli, The Oxford Encyclopedia of Philosophy, Science, and Technology in Islam. Oxford University Press, Oxford 2014.

Kármán-Kunčević 2013 G. Kármán, L. Kunčević, The European Tributary States of the Ottoman Empire in the Sixteenth and Seventeenth Centuries. Brill, Leiden 2013.

Karim 1960 Abdul Karim, Corpus of the Muslim Coins of Bengal: (down to A. D. 1538). Dacca Asiatic Society of Pakistan, Vol. 6, Dacca 1960.

Khismatulin 2015 A. Khismatulin, "Two Mirrors for Princes Fabricated at the Seljuq Court: Nizām alMulk's Siyar al mulūk and al-Ghazālī's Nasīhat al-mulūk". Ed. Edmund Herzig and S. Stewart, I. B. Tauris, The Age of the Seljuqs, The Idea of Iran VI. London (2015) 94-130.

Kurpalidis 1993 G. M. Kurpalidis, "The Seljuqids and the Sultan's Power". Eds. Barbara KellnerHeinkele, Otto Harrassowitz, Altaica Berolinensia: The Concept of Sovereignty in the Altaic World. Permanent International Altaistic Conference, $34^{\text {th }}$ meeting, Berlin 21-26 July, 1991, Wiesbaden (1993) 133-138.

Lafrate 2015 A. Lafrate, The Wandering Throne of Solomon: Objects and Tales of Kingship in the Medieval Mediterranean. Brill, Leiden 2015.

Lane 1865 E. W. Lane, The Tousand and One Nights, commonly called, in England, the The Arabian Nights' Entertainments: a New Translation from the Arabic, with Copious Notes. Routledge, Warne, and Routledge, London 1865.

Lloyd - Rice $1958 \quad$ S. Lloyd - D. S. Rice, Alanya ('Ală'iyya). BIAA, London 1958.

Lowry $2012 \quad H$. W. Lowry, The Nature of the Early Ottoman State. SUNY Press, New York 2012.

Mardrus-Mathers II, 1996 The Book of the Thousand Nights and One Night. Trans. J. C. Mardrus, P. Mathers, Vols. I-IV, II, Routledge, London \& New York 1996.

Masudi 1989 Masudi, The Meadows of Gold: The Abbasids. Trans. P. Lunde-C. Stone, Kegan Paul International, London 1989.

Met 2016 S. R. Canby, D. Beyazit, M. Rugiadi, A. C. S. Peacock, Court and Cosmos: The Great Age of the Seljuqs. Metropolitan Museum of Art, New York 2016.

Mirhand 2015 M. b. H. b. M. Mîrhând, Ravzatu's-Safâ fi Sîreti'l-Enbiyâ ve'l-Mülūk ve'l-Hulefâ (Tabaka-i Selçūkiyye). Çev. E. Göksu, TTK Yay. Ankara 2015.

Mottahedeh 2013 R. P. Mottahedeh, "The Eastern Travels of Solomon: Reimagining Persopolis and the Iranian Past". Eds. M. Cook, N. Haider, I. Rabb, A. Sayeed, Law and Tradition in Classical Islamic Thought: Studies in Honor of Professor Hossein Modaressi, Palgrave Macmillan, Basingstoke, Hampshire (2013) 247-268.

Mousavi 2012 A. Mousavi, Persepolis: Discovery and Afterlife of a World Wonder. Walter de Gruyter, Berlin 2012. 
Naaman 2016

Nasr-Aminrazavi 2008

Nicholson (1921) 1980

Nizami 1881

Nizami 1924

Northrup 1998

Ölçer 2005

Öney 1976

Öney 1980

Öney 1986

Öney 1992

Pançaroğlu 2005

Pereira 1966

Al-Qaddūmī 1996

Ravendi 1999

Redford 2000

Redford 2009

Redford 2015

Renard 1998

Renard 2014

Rogers 1998

Sâdi 1974

Sarre-Herzfeld 1911

Sela 2011
E. Naaman, Literature and the Islamic Court: Cultural life under al-Sahib Ibn 'Abbad, Routledge, London 2016.

S. H. Nasr - M. Aminrazavi, Anthology of Philosophy in Persia: Ismaili Thought in the Classical Age. I. B. Tauris, London Vol. II, 2008.

R. A. Nicholson, Studies in Islamic Mysticism. Cambridge University Press, Cambridge 1921.

Shaikh Nizami of Ganja, Sikandernama. Trans. Wilberforce Clarke, V. I. Publishers, New Delhi 1881.

The Haft Paikat of Nizāmī of Ganja. Trans. \& commentary, C. E. Wilson, Arthur Probsthain, London, Vol. I, 1924.

L. Northrup, From Slave to Sultan: The Career of Al-Manșūr Qalāwūn and the Consolidation of Mamluk Rule in Egypt and Syria (678-689 A.H./1279-1290 A.D.). Franz Steiner Verlag 1998.

N. Ölçer, "The Anatolian Seljuks". Ed. David J. Roxburgh, Turks: A Journey of a Thousand Years. 600-1600, Royal Academy of Arts, London (2005) 104-144.

G. Öney, "Kubadabad Ceramics". Ed. W. Watson, The Art of Iran and Anatolia from $11^{\text {th }}$ to the $12^{\text {th }}$ Centuries A.D., Colloquies on Art and Archeology in Asia, No. 4, University of London, the Percival David Foundation of Chinese Art, School of Oriental and African Studies, London (1976) 68-84.

G. Öney "Architectural Decoration and the Minor Arts". Ed. E. Akurgal, The Art and Architecture of Turkey, Rizzoli, New York (1980) 170-207.

G. Öney, Turkish Traditional Arts, Vol. II. Tiles, Turkish Republic, Ministry of Culture and Tourism, General Directorate of Fine Arts, Ankara 1986.

G. Öney, Anadolu Selçuklu Mimari Süslemesi ve El Sanatları. Türkiye İş Bankası, Ankara 1992.

O. Pançaroğlu, "Cat. Nos. 59-68". Ed. David J. Roxburgh, Turks: A Journey of a Thousand Years, 600-1600. Royal Academy of Arts, London (2005) 392-394.

M. Pereira, Mountains and Shore: A Journey Through Southern Turkey. Geoffrey Bles, London 1966.

Al-Qaddūmī, The Book of Gifts and Rarities - Kitāb al-Hadāyā wa al-Tuhaf. Trans. \& Ed. G. H. Al-Qaddumi, Cambridge, Mass. 1996.

M. B. Ali b. Süleyman er-Ravendi, Rahat-üs-Sudur ve Ayet-us-Sürur. Trans. A. Ateş, I, II, TTK, Ankara 1999.

S. Redford, Landscape and the State in Medieval Anatolia. British Archaeological Reports, Oxford 2000.

S. Redford, "The inscription of the Kırkgöz Hanı and the Problem of Textual Transmission". ADALYA XII (2009) 347-360.

S. Redford, "Anatolian Seljuk Palaces and Gardens". Michael Featherstone, JeanMichel Spieser, Gülru Tanman, The Emperor's House: Palaces from Augustus to the Age of Absolutism, Walter de Gruyter (2015) 231-242.

J. Renard, Windows on the House of Islam: Muslim Sources on Spirituality and Religious Life. University of California Press, Berkeley-London 1998.

J. Renard, Islamic Theological Themes: A primary source reader. University of California Press, Oakland, CA 2014.

J. M. Rogers, "Seton Lloyd's and D. S. Rice's Survey of Alanya ('Alā'iyya, 'Alâ'ye)". Ed R. Matthews, Ancient Anatolia: Fifty Years' work by the British Institute of Archaeology at Ankara, London (1998) 367-378.

Sâdi, The Rose Garden of Shekh Muslihu'd-Din Sadi of Shiraz. Trans. E. B. Eastwick. London 1974.

F. Sarre \& E. Herzfeld, Archeäologische Reise im Euphrat und Tigris Gebiet Mit Einem Beitrage: Arabische Inschriften Von Max Van Berchem. Vols. 1-4. Berlin 1911-1920.

R. Sela, The Legendary Biographies of Tamerlane: Islam and Heroic Apocrypha in Central Asia. Cambridge University Press, Cambridge 2011. 
Schimmel 2014

Schöttler 1989

Smoor 1991

Southgate 1978

Stoneman 1991

Stoneman 2012

Ṭabarī 1985

Venetis 2007

De Weese 1999

Yamanaka-Nishio 2006

El-Zein 2009

Zuwiyya 2011
A. Schimmel, A Two-Coloured Brocade: The imagery of Persian Poetry. The University of North Carolina 2014.

P. Schöttler Turkey: A Phaidon Cultural Guide in colour. Ed. M. Mehling, Oxford 1989.

P. Smoor, "Palace and Ruin, a Theme for Fāțimid Poets?". Die Welt des Orients, Bd. 22 (1991) 94-104.

M. S. Southgate, Iskandarnamah: A Persian Medieval Alexander-Romance. Columbia University Press, New York 1978.

R. Stoneman, The Greek Alexander Romance. Penguin, London 1991.

R. Stoneman, The Alexander Romance in Persia and the East. Barkhuis Publishing and Groningen University Library, Groningen 2012.

The History of Al-Tabari: The Children of Israel. Trans. William M. Brinner, SUNY, New York 1985.

A. Venetis, "Warlike Heroines in the Persian Alexander Tradition: The cases of Araqit and Burandukht". Iran 45 (2007) 227-232.

D. De Weese, "Kubrawī Hagiographical Traditions". Ed. L. Lewisohn, The Heritage of Sufism: The Legacy of Medieval Persian Sufism (1150-1500), Oneworld, Oxford (1999) 212-158.

Y. Yamanaka-T. Nishio, The Arabian Nights and Orientalism: Perspectives from East and West. I. B. Tauris, London 2006.

A. El-Zein, Islam, Arabs, and the Intelligent World of the Jinn. Syracuse University Press, Syracuse, NY 2009.

Z. D. Zuwiyya, "The Alexander Romance in the Arabic Tradition". A Companion to Alexander Literature in the Middle Ages, Brill, Leiden (2011) 73-113. 